Pacific Northwest

National Laboratory

Operated by Battelle for the

U.S. Department of Energy

\section{A Comparison of Eight National Monuments as Applied to the Hanford Reach National Monument}

A. J. Pospical

August 2004

Prepared for the U.S. Department of Energy under Contract DE-AC06-76RL01830 


\title{
DISCLAIMER
}

This report was prepared as an account of work sponsored by an agency of the United States Government. Neither the United States Government nor any agency thereof, nor Battelle Memorial Institute, nor any of their employees, makes any warranty, express or implied, or assumes any legal liability or responsibility for the accuracy, completeness, or usefulness of any information, apparatus, product, or process disclosed, or represents that its use would not infringe privately owned rights. Reference herein to any specific commercial product, process, or service by trade name, trademark, manufacturer, or otherwise does not necessarily constitute or imply its endorsement, recommendation, or favoring by the United States Government or any agency thereof, or Battelle Memorial Institute. The views and opinions of authors expressed herein do not necessarily state or reflect those of the United States Government or any agency thereof.

\author{
PACIFIC NORTHWEST NATIONAL LABORATORY \\ operated by \\ BATTELLE \\ for the \\ UNITED STATES DEPARTMENT OF ENERGY \\ under Contract DE-AC06-76RL01830
}

Ty 


\title{
A Comparison of Eight National Monuments as Applied to the Hanford Reach National Monument
}

\author{
A. J. Pospical
}

August 2004

Prepared for

the U.S. Department of Energy

under Contract DE-AC06-76RL01830

Pacific Northwest National Laboratory

Richland, Washington 99352 


\section{Summary}

On June 9, 2000, President William Clinton issued a proclamation to preserve 195,000 acres of land as a national monument in southeastern Washington State. Named the Hanford Reach Monument, it is managed by the U.S. Fish and Wildlife Service. The monument has been preserved by unusual circumstances: for the past 50 years, it has served as the buffer area to one of the U.S. Department of Energy's nuclear reservations. As such, it has been allowed to remain wild, protecting it from human interference and preserving a number of important resources once found in abundance, but now in decline, throughout the Columbia River Basin. At the centerpiece of this monument is the last free-flowing, non-tidal stretch of the Columbia River. Called the Hanford Reach, this 51-mile long section of the Columbia River supports one of the most productive spawning grounds for Chinook salmon. In addition to its natural resources, this monument also contains sites of rich and important archaeological and historical significance.

The U.S. Fish and Wildlife Service is currently working with the U.S. Department of Energy, the public, and a number of other interested parties to create a monument management plan, which is expected to be released sometime in mid-2004. But because of the unusual circumstances that have preserved this monument for the last 50 years, there are unique issues that must be addressed before this monument may be opened to the public. The purpose of this document is to evaluate the recreational land-usage patterns common to our nation's national monuments and apply those findings to what recreational activities are being considered and planned at the Hanford Reach National Monument. Based on these evaluations and taking the unique situation at the Hanford Site into consideration, recommendations are offered for the future management of the Hanford Reach National Monument. 


\section{Contents}

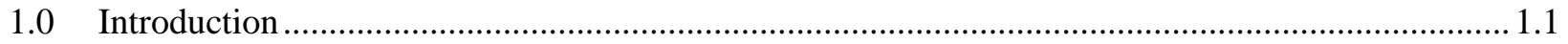

2.0 Hanford Site and the Hanford Reach National Monument ........................................................ 2.1

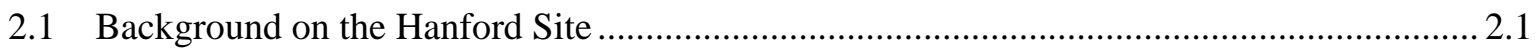

2.2 Background on the Hanford Reach National Monument ..................................................... 2.2

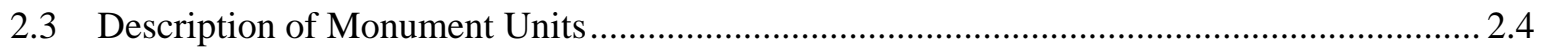

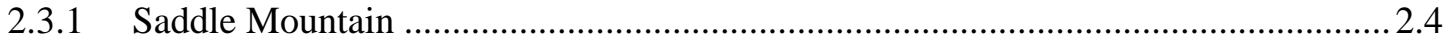

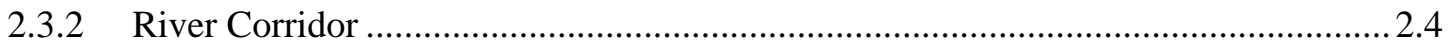

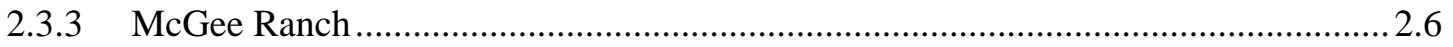

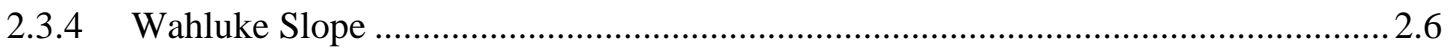

2.3.5 Fitzner/Eberhardt Arid Lands Ecology Reserve.........................................................2.6

2.4 Status of the Hanford Reach National Monument Management Plan.................................. 2.6

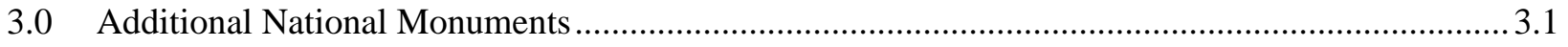

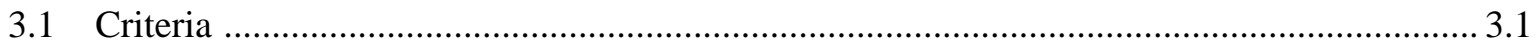

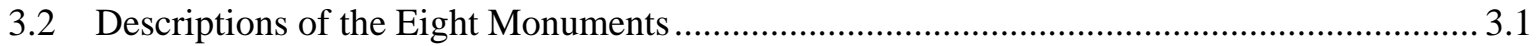

3.2.1 Agua Fria National Monument.............................................................................. 3.1

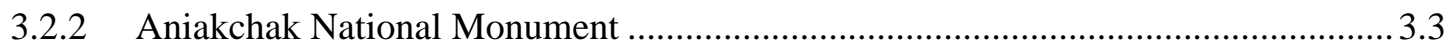

3.2.3 Black Canyon of the Gunnison National Monument .................................................. 3.3

3.2.4 Cascade-Siskiyou National Monument …..................................................................... 3.3

3.2.5 Carrizo Plain National Monument …........................................................................... 3.3

3.2.6 Grand Canyon-Parashant National Monument ............................................................. 3.4

3.2.7 Grand Staircase-Escalante National Monument....................................................... 3.4

3.2.8 Upper Missouri River Breaks National Monument.................................................. 3.4

$4.0 \quad$ Usage

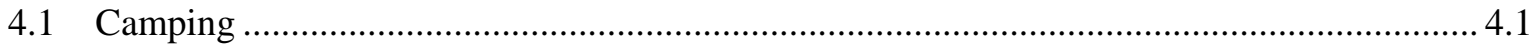

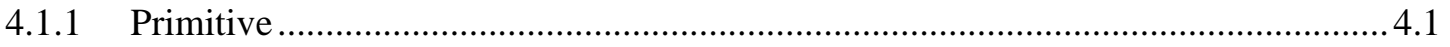




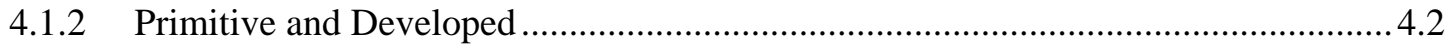

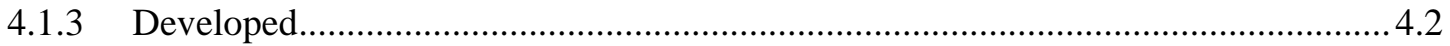

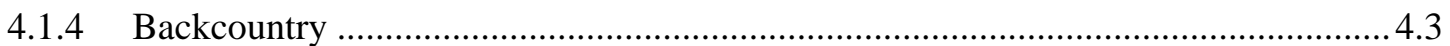

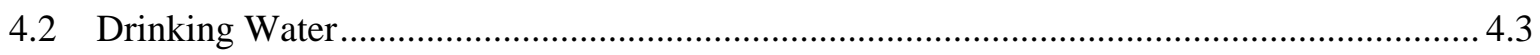

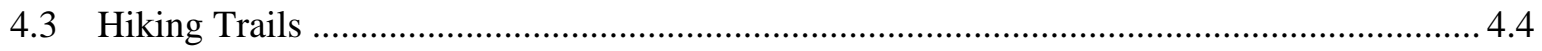

4.3.1 Underdeveloped …........................................................................................... 4.4

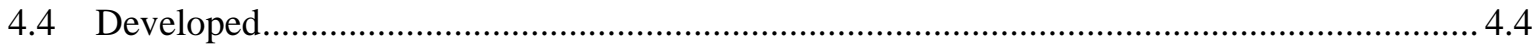

4.4.1 Nationally Designated Trails..................................................................................... 4.5

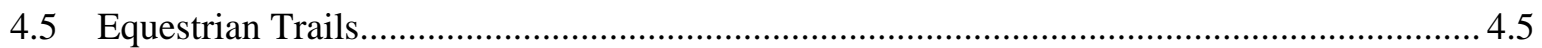

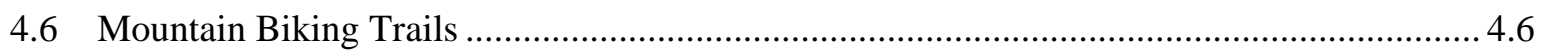

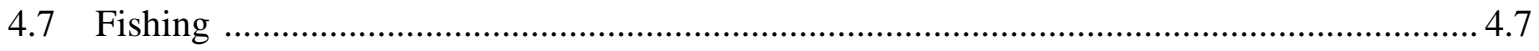

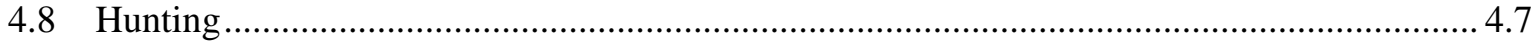

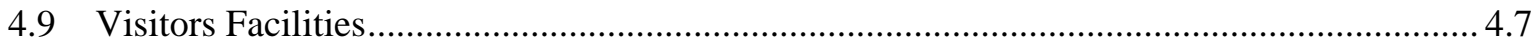

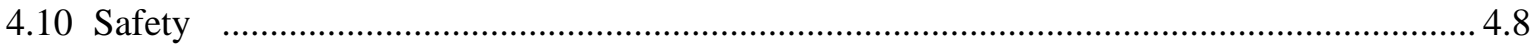

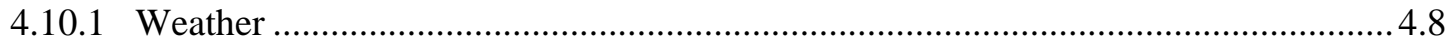

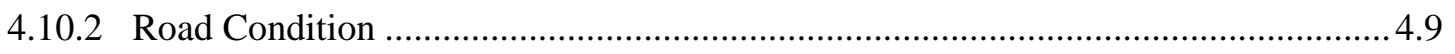

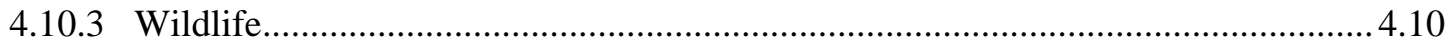

$5.0 \quad$ Hanford Reach National Monument …....................................................................................... 5.1

5.1 Uniqueness of the Hanford Reach National Monument...................................................... 5.1

5.2 Currently Permitted Recreational Activities ...................................................................... 5.2

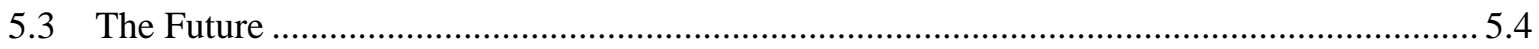

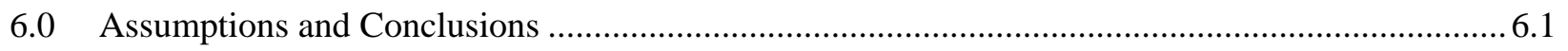

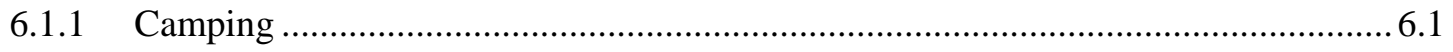

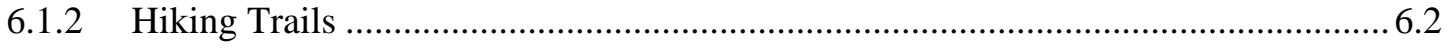

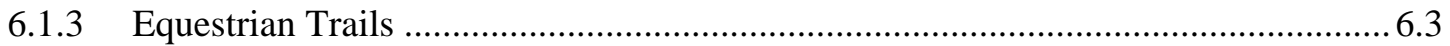

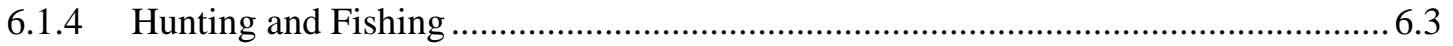

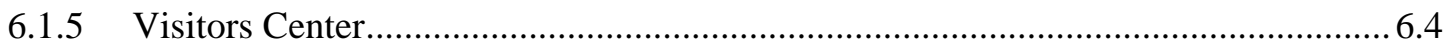




\section{Figures}

2.1. Hanford Site Location Map-Where Hanford Is.....

2.2. A View of the Columbia River on the Hanford Reach National Monument (Wildlife and Environmental Studies 2003).

2.3. The Umtanum Desert Buckwheat.

2.4. The Remains of a Log Cabin, the Last Standing Structure from the 19th Century Homesteads That Once Dotted the Landscape

2.5. Land-Use Map Showing the Hanford Reach National Monument

4.1. Camping at the Black Canyon of the Gunnison........................................................................... 4.2

4.2. Hiking on the Pacific Crest National Scenic Trail ....................................................................... 4.5

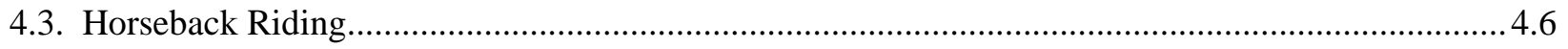

4.4. Hunting on the Carrizo Plain National Monument ........................................................................... 4.8

4.5. Road Conditions on the Grand Staircase-Escalante National Monument....................................... 4.10

5.1. Map of the Hanford Reach Depicting the Shrinking of the Hanford Site and Marking the Locations of the Units of the Hanford Reach National Monument ................................................. 5.2

5.2. A View of the Columbia River on the Hanford Reach National Monument ....................................5.3

5.3. The B Reactor. Left: The B Reactor During Construction. Top Right: The B Reactor During Active Use. Bottom Right: The B Reactor Today

\section{Tables}

3.1. Eight National Monuments Chosen for Evaluation

4.1. Activities Available at National Monuments. 


\subsection{Introduction}

In 1906, Congress passed the American Antiquities Act to preserve and protect lands of significant value to our nation. The act specified that the President or Congress could create national monuments to "protect objects of archeological, scientific, or historical interest.” The act was designed to limit such designations to the smallest amount of land to protect such objects (American Antiquities Act of 1906). Since 1906, both Presidents and Congress have designated 93 national monuments (National Parks and Monuments 2003). Each of these lands, which range in size from 1 acre to 1,700,000 acres, provides opportunities for current and future generations to discover, explore, and experience some of the last great landscapes and open spaces our country has to offer (National Landscape Conservation System 2002).

On June 9, 2000, President William Clinton issued a proclamation to set apart and preserve 195,000 acres of land as a national monument in southeastern Washington State. The monument was named the Hanford Reach National Monument (Proclamation 2000). The monument has been preserved by unusual circumstances: for the past 50 years, it has served as the buffer area to one of the U.S. Department of Energy's (DOE) nuclear reservations. As such, it has been allowed to remain wild, protecting it from human interference and preserving a number of important resources once found in abundance, but now in decline, throughout the Columbia River Basin (Hanford Reach National Monument Brochure 2003). It contains the largest remnant of the shrub-steppe ecosystem once found throughout the Basin. At the centerpiece of this monument is the last free-flowing, non-tidal stretch of the Columbia River. Called the Hanford Reach, this 51-mile long section of the Columbia River supports one of the most productive spawning grounds for Chinook salmon. In addition to its natural resources, this monument also contains sites of rich and important archaeological and historical significance. Hundreds of prehistoric and historic sites spanning more than 10,000 years have been discovered and preserved (Proclamation 2000).

The monument is to be managed by the U.S. Fish and Wildlife Service (USFWS). It is the first such designation for the USFWS in the lower 48 states (Saddle Mountain Unit 2002). The USFWS is currently working with the DOE, the public, and a number of other interested parties to create a monument management plan, which is expected to be released sometime in mid-2004 (Hanford Reach National Monument Brochure 2003). But because of the unusual circumstances that have preserved this monument for the last 50 years, there are unique issues that must be addressed before this monument may be opened to the public. At the forefront of these issues is the clean up of legacy waste left over from the Hanford Site's World War II and Cold War plutonium production and nuclear weapons research. This past history will dictate what land uses will be permitted on the monument, including specifically what recreational activities will be allowed. Cleanup at the Hanford Site will strive to eliminate major threats to human health and the environment, protect the groundwater and the Columbia River, and free up large stretches of land (much of it along the shoreline) for recreational uses (DOE/RL 2003). But how will land uses of what is being proposed at the Hanford Reach National Monument look in comparison to other similar national monuments? The purpose of this document is to evaluate the recreational land-usage patterns common to our nation's national monuments and apply those findings to what recreational activities are being considered and planned at the Hanford Reach National Monument. This document will also look at the challenge of communicating public risk to monument visitors and applying those findings to the unique nature of the Hanford Reach National Monument. 


\subsection{Hanford Site and the Hanford Reach National Monument}

\subsection{Background on the Hanford Site}

The Hanford Site (Figure 2.1) is located in the southeastern corner of Washington State near where the Yakima and Snake Rivers meet the Columbia River. The site contains approximately $586 \mathrm{mi}^{2}$ of semiarid shrub and grasslands. It includes the last free-flowing stretch of the Columbia River, the Fitzner/Eberhardt Arid Lands Ecology Reserve, and the Saddle Mountain National Wildlife Refuge, as well as a number of other cultural, biological, and natural resources (DOE/RL 2003).

The evolution of the Hanford Site into its current state began in 1943. Before then, the Hanford area was home to about 1,200 residents, mostly farmers. In 1942, the first controlled and sustained nuclear reaction was accomplished in Chicago. A month later, Hanford was chosen as one of a small number of plutonium production sites because of its remote and secluded location and abundant supply of water from the Columbia River. The super-secret project, named the Manhattan Project, involved other facilities in Tennessee and New Mexico. The federal government purchased the land from the local residents and relocated them out of the area (Hanford Site Selection 2003).

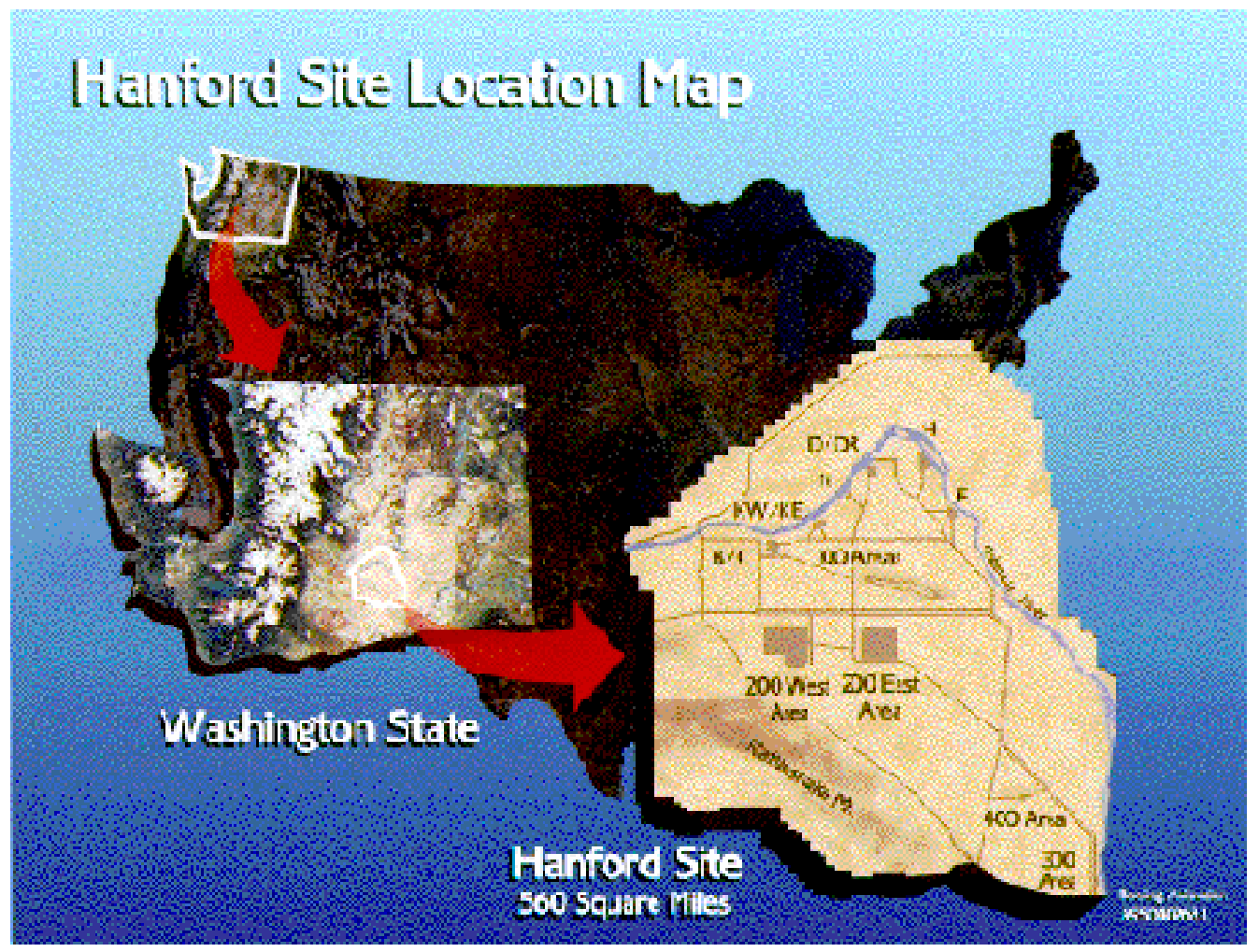

Figure 2.1. Hanford Site Location Map. 
Over the last 50 years, the Hanford Site has continued to play a pivotal role in our nation's defense. The Manhattan Project was officially completed in 1947. From 1947 to 1989 when the production mission ended, the Site was heavily involved in supporting the nation's Cold War efforts.

In 1989 portions of the Site were placed on the Comprehensive Environmental Response, Compensation, and Liability Act of 1980 (CERCLA) National Priorities List (NPL) as contaminated sites requiring cleanup action. In anticipation of the NPL listing, the U.S. Department of Energy, Richland Operations Office (RL) entered in the Hanford Federal Facility Agreement and Consent Order (89-10) (Tri-Party Agreement), with the U.S. Environmental Protection Agency (EPA) and the Washington State Department of Ecology (Ecology). The Tri-Party Agreement establishes the legal framework and schedule for cleanup (DOE/RL 2003, 1-3).

Today, the Hanford Site's mission is the largest environmental cleanup project in the world. Cleanup efforts are focused on three outcomes: restoring the Columbia River Corridor (Figure 2.2) for other uses, transitioning the Central Plateau to long-term waste treatment and storage, and preparing for the future. The completion of cleanup remains several decades away (completion of the cleanup is scheduled for 2035 or earlier); however, as cleanup is completed on individual parcels of land, they will be transitioned to long-term stewardship for management (DOE/RL 2003).

\subsection{Background on the Hanford Reach National Monument}

Established on June 9, 2000, the Hanford Reach National Monument is a unique and biologically diverse landscape containing an irreplaceable natural and historic legacy. The monument has been preserved by the unusual circumstances of having been a federal nuclear reservation for 50 years: "With limited human development and livestock grazing, native plants and animals have thrived, and a diverse archaeological record has been preserved” (Hanford Reach National Monument Brochure 2003).

Located north of Richland, Washington, the monument contains 195,000 acres and is home to some of the last remaining riparian, aquatic, and upland shrub-steppe habitat in Washington State (Hanford Reach National Monument Brochure 2003). Within these habitats, the monument supports a number of native plant and animal species that include fish, birds, mammals, and reptiles (Proclamation 2000).

The large blocks of rare shrub-steppe ecosystems contain a rather high diversity of native plants. They include two recently discovered plant species: the Umtanum desert buckwheat (Figure 2.3) and the White Bluffs Bladderpod. The shrub-steppe also supports a significant breeding population of shrub-steppedependant birds. The Hanford Reach and surrounding wetlands also provide an important habitat for migratory birds as well as many resident bird species. Elk, beaver, badgers, and bobcats can also be found on the monument where they have thrived over the last 50 years with very little human contact (Proclamation 2000).

The monument also includes, at its centerpiece, the 51-mile stretch of the Columbia River called the Hanford Reach. The Reach is the last free-flowing, non-tidal stretch of the Columbia River. Dams exist above and below this stretch of the river, but the Reach has never been dammed or dredged, which has created a habitat that is characteristic of an undammed river (Proclamation 2000). 


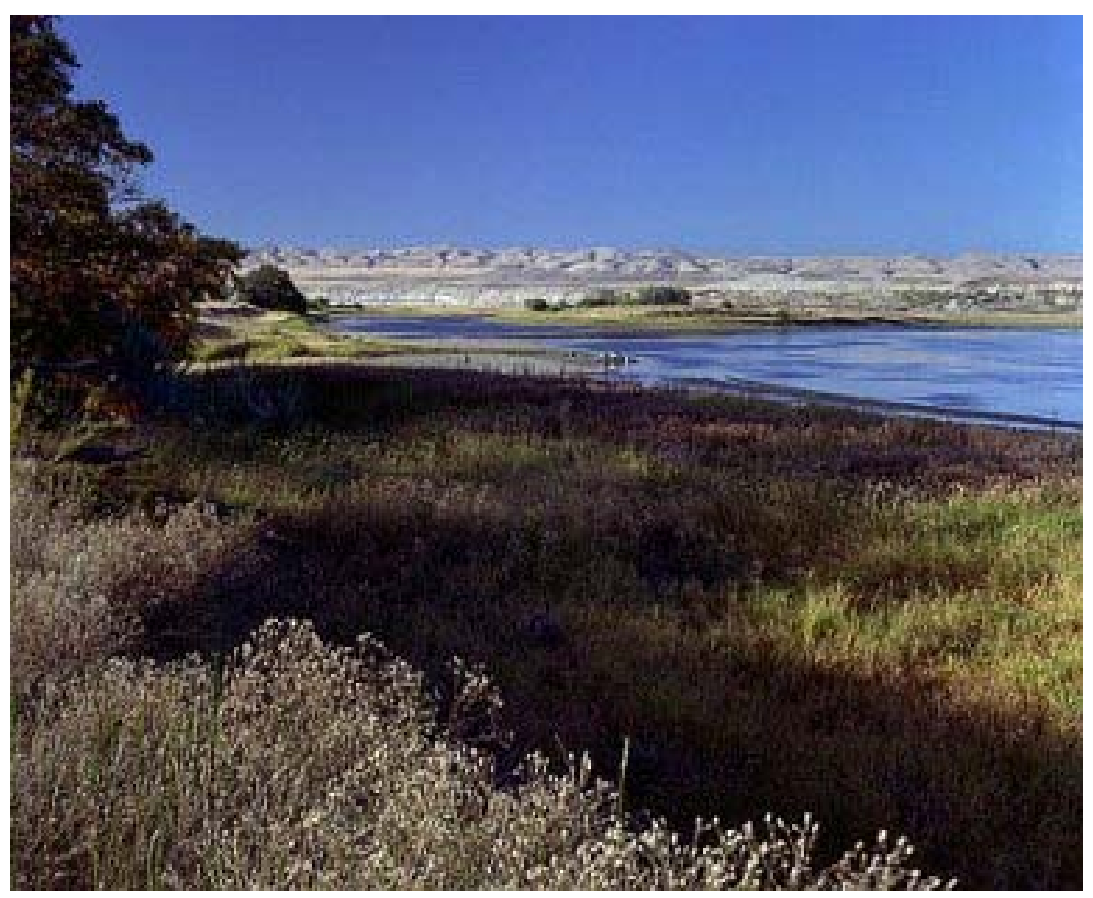

Figure 2.2. A View of the Columbia River on the Hanford Reach National Monument (Wildlife and Environmental Studies 2003)

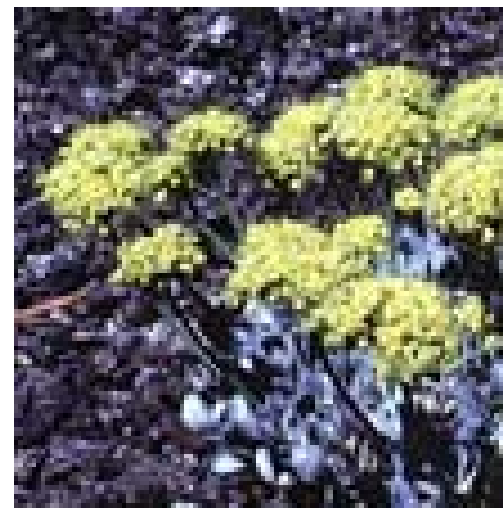

Figure 2.3. The Umtanum Desert Buckwheat

The Reach's unique and untouched habitat supports some of the northwest's most productive salmon spawning grounds. Nearly $80 \%$ of all upper Columbia fall Chinook salmon return to the Reach to spawn, as well as 43 other species of fish (Proclamation 2000 and Hanford Reach National Monument Brochure 2003).

The monument is also archaeologically and historically significant. Human activity over the last 10,000 years has left behind extensive archaeological sites that have been discovered, "including remains of pithouses, graves, spirit quest monuments, hunting camps, game drive complexes, quarries, and hunting and kill sites” (Proclamation 2000). A number of Native American groups, including the 
Wanapum, Nez Perce, and Yakama tribes and the tribes and bands of the Umatilla Indian Reservation, still have important cultural ties to the area. The monument also contains the remains of a small town established in the 20th century along the Columbia River (Proclamation 2000) and the remains of a log cabin built in the $19^{\text {th }}$ century (Figure 2.4 ).

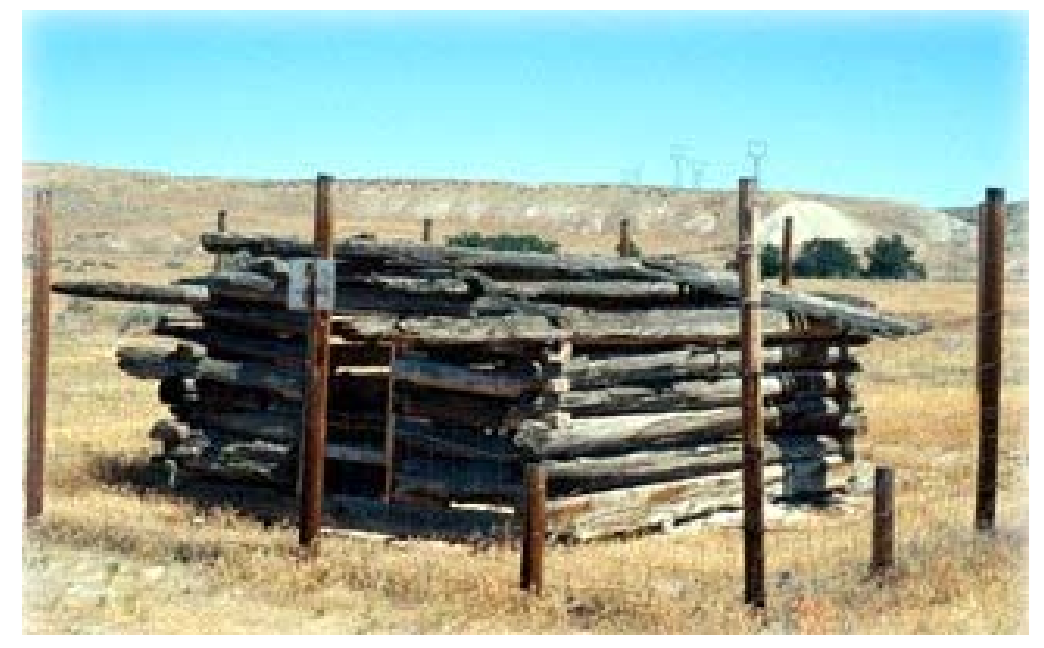

Figure 2.4. The Remains of a Log Cabin, the Last Standing Structure from the 19th Century Homesteads That Once Dotted the Landscape. The log cabin was built in 1894 (The Monument’s History 2002).

The Hanford Reach National Monument is divided into five administrative units. The units are managed by two federal agencies: the USFWS and the DOE (Hanford Reach National Monument Brochure 2003). The units are the Wahluke Unit, the Saddle Mountain Unit, the McGee Ranch/Riverlands Unit, the Fitzner/Eberhardt Arid Lands Ecology Reserve, and the River Corridor Unit (see Figure 2.5) (Hanford Reach National Monument Brochure 2003).

\subsection{Description of Monument Units}

\subsubsection{Saddle Mountain}

Saddle Mountain is located on the north shore of the Columbia River and serves as a wildlife preserve. This unit, which is currently off limits to the public, contains dense stands of sagebrush and provides a home for many protected bird species (Hanford Reach National Monument Brochure 2003). The most prominent features include a portion of the Wahluke Slope, the western end of the White Bluffs, the southwestern slopes of the Saddle Mountains, and a portion of the Hanford Reach. The unit serves as a place for ecological research and environmental education (Saddle Mountain Unit 2002).

\subsubsection{River Corridor}

The River Corridor contains 25,000 acres along the south and west banks of the Columbia River as well as the Hanford sand dunes and the 16 Columbia River islands that exist in the main channel of the Reach (Hanford Reach National Monument Brochure 2003). It is the last free-flowing, non-tidal stretch of the 
Columbia River within the United States. The area supports one of the largest fall Chinook salmon spawning grounds in the Columbia River. Nearly $90 \%$ of all Chinook salmon return to the Hanford Reach to spawn (Columbia River Corridor 2002).

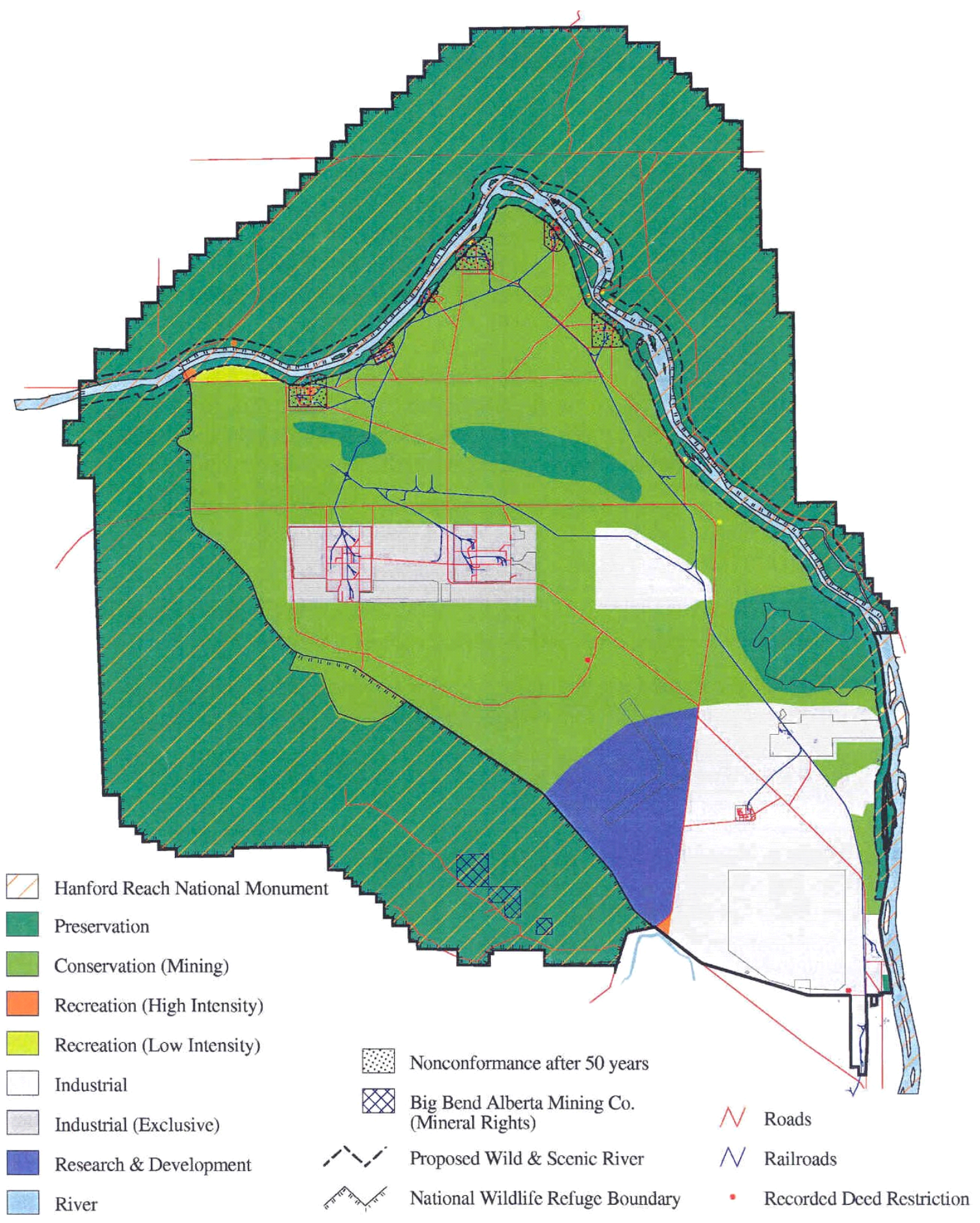

Figure 2.5. Land-Use Map Showing the Hanford Reach National Monument (DOE/RL 2003) 


\subsubsection{McGee Ranch}

McGee Ranch contains 9,000 acres and provides a protected corridor for wildlife between the Arid Land Ecology Reserve and the U.S. Army's Yakima Training Center. The unit was a former pioneer ranch and contains a number of unique and rare plants (Hanford Reach National Monument Brochure 2003). These rare plants include Hoover's desert parsley, the Kittitas larkspur, and the Umtanum desert buckwheat-a federal candidate species found no where else in the world. The most prominent features include the eastern end of the Umtanum Ridge, China Bar, and the Hanford Reach (McGee Ranch/Riverlands Unit 2002).

\subsubsection{Wahluke Slope}

The Wahluke Slope contains 57,000 acres of the monument's most diverse riparian and shrub-steppe habitats. Near the center of this unit lies the Wahluke Lake, formed by water returning to the river from irrigated lands. Bulrush and cattails provide nesting sites for several bird species. The unit also contains the spectacular White Bluffs, which line the Columbia River for about 20 miles. The Bluffs are a result of deposits of gravel, sand, and mud from ancient lakes, the river, and its tributaries (Hanford Reach National Monument Brochure 2003). The most prominent features include a portion of the Wahluke Slope and the Saddle Mountains, the White Bluffs, and the large dune fields above the Bluffs (Wahluke Unit 2002).

\subsubsection{Fitzner/Eberhardt Arid Lands Ecology Reserve}

The Fitzner/Eberhardt Arid Lands Ecology Reserve contains 77,000 acres of land. Its prominent features include the ridge top and mostly north-facing slope of the Rattlesnake Mountain (the highest "treeless" mountain in the United States), portions of the Rattlesnake Hills, and the east end of the Yakima Ridge. This unit contains one of the few remaining large tracts of the native habitat that once characterized this region. In 2000, a major wildfire burned most of this unit and devastated the native habitat. Today, native grasslands are recovering, and efforts are being made to restore sagebrush to the area. The unit currently serves as a place for ecological research and environmental education (Fitzner/Eberhardt Arid Lands Ecology Reserve 2002).

\subsection{Status of the Hanford Reach National Monument Management Plan}

The Hanford Reach National Monument Management Plan is currently in the planning stages. The status of the plan, according to the USFWS's Hanford Reach National Monument Brochure (2003) and Saddle Mountain Unit (2003), is as follows:

The service is currently working with a local advisory committee, Native Americans, and the public to complete a management plan for the Monument. The plan will address visitor access, facilities, and management actions needed to provide for the long-term protection of the Monument. (Hanford Reach National Monument Brochure 2003). 


\subsection{Additional National Monuments}

\subsection{Criteria}

The United States has 93 national monuments in the contiguous states and Alaska. Of these monuments, the smallest is the Castle Clinton National Monument located in southeastern New York, which is a mere 1 acre in size. The largest national monument, on the other hand, is the Grand Staircase-Escalante National Monument in southern Utah; it contains nearly 1,700,000 acres of land. Of the 93 national monuments, 64 are west of the Rocky Mountains (National Parks and Monuments 2003).

Since the purpose of this document is to evaluate the recreational usage patterns common to national monuments and apply that knowledge to what is being considered and planned at the Hanford Reach National Monument, it was decided the number of monuments studied should be limited. Criteria were developed to aid in selecting sites that shared certain features in common with the Hanford Reach National Monument. These criteria are the following:

- location (west of the Rocky Mountains)

- size

- presence of a river or body of water

- landscape

- Native American significance to the land

- presence of a reserve.

The eight sites listed in Table 3.1 were selected for further evaluation and comparison against the Hanford Reach National Monument.

\subsection{Descriptions of the Eight Monuments}

\subsubsection{Agua Fria National Monument}

In January 2000, President Clinton declared 71,000 acres of federal land to be the Agua Fria National Monument. The monument encompasses two mesas and the canyon of the Agua Fria River. "This expansive mosaic of semi-desert area, cut by ribbons of valuable riparian forest, offers one of the most significant systems of prehistoric sites in the American Southwest” (Agua Fria National Monument Fact Sheet 2003). Its ancient ruins offer insights into the lives of those who once inhabited this part of the desert southwest. At least 450 prehistoric sites are known to exist. In addition to its rich record of human history, the monument contains outstanding biological resources including pristine riparian habitat, and topographical features and relatively available water provide habitat for a wide range of sensitive species and other wildlife. The monument is managed by the Arizona Bureau of Land Management (Agua Fria National Monument Fact Sheet 2003). 
Table 3.1. Eight National Monuments Chosen for Evaluation

\begin{tabular}{|c|c|c|c|c|c|c|}
\hline $\begin{array}{l}\text { National } \\
\text { Monument }\end{array}$ & Location & Acreage & Total Visits & Managing Agency & $\begin{array}{c}\text { Other } \\
\text { Designations }\end{array}$ & Body of Water \\
\hline Agua Fria, AZ & $\begin{array}{l}\text { Central } \\
\text { Arizona }\end{array}$ & 71,100 & & $\begin{array}{l}\text { Arizona Bureau of } \\
\text { Land Management }\end{array}$ & $\begin{array}{l}\text { National } \\
\text { Monument } \\
\text { January 11, } 2000\end{array}$ & Agua Fria River \\
\hline Aniakchak, AK & SW Alaska & 602,779 & 377 (1999) & $\begin{array}{l}\text { National Park } \\
\text { Service }\end{array}$ & $\begin{array}{l}\text { National } \\
\text { Monument and } \\
\text { Preserve- } \\
\text { December 2, } \\
\text { 1980; National } \\
\text { Wild River- } \\
\text { December 2, } \\
1980\end{array}$ & $\begin{array}{l}\text { Surprise Lake } \\
\text { Aniakchak River }\end{array}$ \\
\hline $\begin{array}{l}\text { Black Canyon of } \\
\text { the Gunnison, CO }\end{array}$ & W. Colorado & 30,300 & $\begin{array}{l}174,346 \\
(2002)\end{array}$ & $\begin{array}{l}\text { National Park } \\
\text { Service }\end{array}$ & $\begin{array}{l}\text { National } \\
\text { Monument - } \\
\text { March 2, 1933; } \\
\text { National Park - } \\
\text { October 21, } 1999\end{array}$ & Gunnison River \\
\hline $\begin{array}{l}\text { Cascade-Siskiyou, } \\
\text { OR }\end{array}$ & $\begin{array}{l}\text { S Central } \\
\text { Oregon }\end{array}$ & 52,000 & & $\begin{array}{l}\text { Oregon Bureau of } \\
\text { Land Management }\end{array}$ & $\begin{array}{l}\text { National } \\
\text { Monument } \\
\text { June 9, } 2000\end{array}$ & $\begin{array}{l}\text { Hyatt Lake } \\
\text { Jenny Creek }\end{array}$ \\
\hline Carrizo Plain, CA & $\begin{array}{l}\text { W. Central } \\
\text { California }\end{array}$ & 204,000 & & $\begin{array}{l}\text { California Bureau } \\
\text { of Land } \\
\text { Management }\end{array}$ & \begin{tabular}{|l} 
National \\
Monument \\
January 17, 2001
\end{tabular} & $\begin{array}{l}\text { Soda Lake (dry } \\
\text { most of the year) }\end{array}$ \\
\hline $\begin{array}{l}\text { Grand Canyon- } \\
\text { Parashant, AZ }\end{array}$ & NW Arizona & $1,014,000$ & & $\begin{array}{l}\text { Managed jointly } \\
\text { by Arizona Bureau } \\
\text { of Land } \\
\text { Management and } \\
\text { the National Park } \\
\text { Service }\end{array}$ & $\begin{array}{l}\text { National } \\
\text { Monument } \\
\text { January 11, } 2000\end{array}$ & N/A \\
\hline $\begin{array}{l}\text { Grand Staircase } \\
\text { Escalante, UT }\end{array}$ & S. Utah & $1,700,000$ & & $\begin{array}{l}\text { Utah Bureau of } \\
\text { Land Management }\end{array}$ & $\begin{array}{l}\text { National } \\
\text { Monument } \\
\text { September 18, } \\
1996\end{array}$ & Escalante River \\
\hline $\begin{array}{l}\text { Upper Missouri } \\
\text { River Breaks, MO }\end{array}$ & $\begin{array}{l}\text { N. Central } \\
\text { Montana }\end{array}$ & 377,346 & & $\begin{array}{l}\text { Montana Bureau of } \\
\text { Land Management }\end{array}$ & $\begin{array}{l}\text { National } \\
\text { Monument } \\
\text { January 17, 2001; } \\
\text { Wild and Scenic } \\
\text { River 1976 }\end{array}$ & Missouri River \\
\hline
\end{tabular}




\subsubsection{Aniakchak National Monument}

In 1978, Congress declared the Aniakchak Caldera a national monument, recognizing the unique geological significance of the caldera and acknowledging the outstanding wildlife and recreational values of the Aniakchak River. The Aniakchak National Monument is located in the volcanically active Aleutian Mountains and covers 603,000 acres surrounding the caldera and the river (Aniakchak National Monument and Preserve 2003a). ${ }^{1}$ The caldera is the result of the collapse of the mountain from a series of eruptions, the last of which took place in 1931. It is nearly 6 miles in diameter and covers an area of nearly $10 \mathrm{mi}^{2}$. The 2000-foot-deep crater contains many outstanding examples of volcanic features, including lava flows, cinder cones, and explosion pits. Located within the caldera is Surprise Lake, the source of the Aniakchak River, which cascades through the 1500-foot-gash in the caldera wall. The river is designated as a Wild and Scenic River (Aniakchak National Monument and Preserve 2003b). Access to the monument and preserve is limited to plane, float plane, or power boat. There are no formal trails or roads within the monument or preserve. The monument is managed by the National Park Service. ${ }^{1}$

\subsubsection{Black Canyon of the Gunnison National Monument}

The Black Canyon of the Gunnison is the oldest of the monuments studied for this document; it was declared a national monument in 1933. The monument's unique and spectacular landscape was formed slowly by the action of the water and rock scouring down through pristine hard Proterozoic crystalline rock (Black Canyon of the Gunnison National Park 2003a). The canyon is one of the most astounding canyons on earth: it is as narrow as 1,100 feet across in places, but its walls plummet 2,900 feet down to the river far below. The monument is managed by the National Park Service.

\subsubsection{Cascade-Siskiyou National Monument}

The Cascade-Siskiyou National Monument has long been recognized as an ecologically diverse area. In 2000, nearly 52,000 acres of land were formally recognized by the President and declared a national monument (Frequently Asked Questions 2002). The monument not only is a biologically diverse and ecologically unique area, but it also contains Soda Mountain, Pilot Rock, and the Siskiyou Pass. The monument is managed by the Oregon Bureau of Land Management.

\subsubsection{Carrizo Plain National Monument}

The Carrizo Plain is an area passed over by time. The undisturbed and unique nature of this area distinguished it, and in 2001, it was declared a national monument (Carrizo Plain National Monument 2003). The Carrizo Plain National Monument is the largest remaining tract of the San Joaquin Valley's biogeographic province with only limited human alterations. It is the largest remaining habitat for a number of endangered, threatened, and rare species of animals. The Plain also provides habitat for many unique plant species. Adding to the unique nature of the monument, the area is also rich with evidence of its prehistoric and historic pasts. The monument is managed by the California Bureau of Land Management.

\footnotetext{
${ }^{1}$ From Printable Travel Guide, a 2003 online guide produced by the National Park Service Aniakchak National Monument (no longer publicly available).
} 


\subsubsection{Grand Canyon-Parashant National Monument}

The Grand Canyon-Parashant National Monument was dedicated in 2000, setting aside nearly 1,000,000 acres of land bordering one of the most beautiful places on earth - the Grand Canyon. The monument is a scientific treasure holding deep canyons, mountains, and lonely buttes testifying to the power of geological forces and providing colorful vistas. Beyond its phenomenal geological resources, the monument contains countless biological, archeological, and historical resources. The monument is managed by the Arizona Bureau of Land Management and the National Park Service.

\subsubsection{Grand Staircase-Escalante National Monument}

The Grand Staircase-Escalante National Monument offers a dramatic landscape rich in natural and human history. Dedicated as a national monument in 1996, the monument extends across nearly 1.7 million acres (Grand Staircase-Escalante National Monument 2003). The monument contains a series of cliffs and plateaus and the canyons of the Escalante River (Description: Grand Staircase-Escalante National Monument 2003). It represents a unique combination of archaeological, historical, paleontological, geographical, and biological resources. The monument is managed by the Utah Bureau of Land Management.

\subsubsection{Upper Missouri River Breaks National Monument}

In 2001, 377,000 acres were added to the National Landscape Monument System. The land, named the Upper Missouri River Breaks National Monument (Upper Missouri River Breaks National Monument 2003a and 2003b), recognizes the unique ecosystem that parallels the Upper Missouri National Wild and Scenic River. The remote location of this monument in north central Montana has preserved a wide array of biological, scientific, historical, wildlife, geological, and cultural resources not commonly found today. The center of the monument is the Upper Missouri River. The remote nature of this segment of the river has preserved the area from human interference and maintained the same vistas that were viewed by Lewis and Clark in 1805 and 1806. The monument is managed by the Montana Bureau of Land Management. 


\subsection{Usage}

Table 4.1 lists the various activities available at the national monuments studied in this report.

Table 4.1. Activities Available at National Monuments

\begin{tabular}{||l|l|l|l|l|l|l|l|l||}
\hline $\begin{array}{c}\text { National } \\
\text { Monument }\end{array}$ & $\begin{array}{l}\text { Visitors } \\
\text { Center }\end{array}$ & Camping & $\begin{array}{l}\text { Drinking } \\
\text { Water }\end{array}$ & Fishing & Hunting & Hiking & Biking & $\begin{array}{c}\text { Equestrian } \\
\text { Trails }\end{array}$ \\
\hline Agua Fria, AZ & No & Yes & No & Yes & Yes & Yes & Yes & No \\
\hline Aniakchak, AK & No & Yes & No & Yes & Yes & Yes & No & No \\
\hline $\begin{array}{l}\text { Black Canyon of the } \\
\text { Gunnison, CO }\end{array}$ & Yes & Yes & $\begin{array}{l}\text { Seasonally } \\
\text { Available }\end{array}$ & Yes & Yes & Yes & No & Yes \\
\hline $\begin{array}{l}\text { Cascade-Siskiyou, } \\
\text { OR }\end{array}$ & No & Yes & No & Yes & Yes & Yes & Yes & Yes \\
\hline $\begin{array}{l}\text { Carrizo Plain, CA } \\
\text { Grand Canyon- } \\
\text { Parashant. AZ }\end{array}$ & Yes & Yes & No & No & Yes & Yes & Yes & Yes \\
\hline $\begin{array}{l}\text { Grand Staircase } \\
\text { Escalante, UT }\end{array}$ & No & Yes & No & Yes & Yes & Yes & Yes & Yes \\
\hline $\begin{array}{l}\text { Upper Missouri } \\
\text { River Breaks, MO }\end{array}$ & No & Yes & No & Yes & Yes & Yes & No & No \\
\hline \hline
\end{tabular}

\subsection{Camping}

In the eight monuments studied in this document, all permitted some form of camping within the monument. Camping sites ranged from a more primitive level of development to a more developed level. All shared a commonality of permitting backcountry camping within the boundaries of the monument.

\subsubsection{Primitive}

Each monument seems to define primitive camping differently. For example, the Aniakchak National Monument has no marked campgrounds or sites anywhere in its nearly 602,000 acres of tundra. Camping in Aniakchak is therefore considered entirely primitive, backcountry camping. Campers at Aniakchak must pack in and pack out all supplies necessary to survive in this remote and treeless monument, which includes heating and cooking equipment (Parks-Aniakchak National Monument and Preserve 2003). Primitive camping tends to be less extreme in the other monuments studied. The Agua Fria, Grand Canyon-Parashant, and the Carrizo Plain National Monument campgrounds are limited to a small number of underdeveloped sites. For example, in the Grand Canyon-Parashant National Monument, it is recommended that campers use the available undeveloped campsites along primary roads, although camping on public lands is allowed throughout the monument (Visitor Information 2003). The Carrizo Plain is the only monument of these four to offer facilities of any kind at their campgrounds. The 
facilities consist of a few portable toilets, picnic tables, and fire rings at two campgrounds (Camping: Carrizo Plain National Monument 2003). The Agua Fria National Monument offers no facilities.

\subsubsection{Primitive and Developed}

The Grand Staircase-Escalante and the Cascade-Siskiyou National Monuments provide visitors with the choice of camping in a primitive or a developed setting. In the Grand Staircase-Escalante National Monument, primitive sites are located in a number of places throughout the monument; they typically consist of undesignated, but repeatedly used, sites. The Grand Staircase-Escalante National Monument has developed sites along the perimeter and two locations inside of the 1.7-million-acre monument. By Grand Staircase-Escalante's definition, these developed sites include recreational vehicle hookups, picnic tables, grills, restrooms, and showers (Camping and Lodging: Grand Staircase-Escalante National Monument 2002). The Cascade-Siskiyou National Monument offers developed campgrounds at the Hyatt Lake Recreational Complex located inside the monument. However, the Complex existed before the area was named a monument (Hyatt Lake Recreation Complex 2002). Camping within the remaining 52,000 acres is considered primitive.

\subsubsection{Developed}

The Black Canyon of the Gunnison National Monument is the only national monument that offers primarily developed camping (see Figure 4.1). Park officials consider the campground at the South Rim of the canyon to be the most developed. Vehicles are permitted up to 35 feet in length. The campgrounds at the North Rim are considered to be less developed, but vehicles up to 35 feet in length are permitted as well (Camping: Black Canyon of the Gunnison National Park 2003).

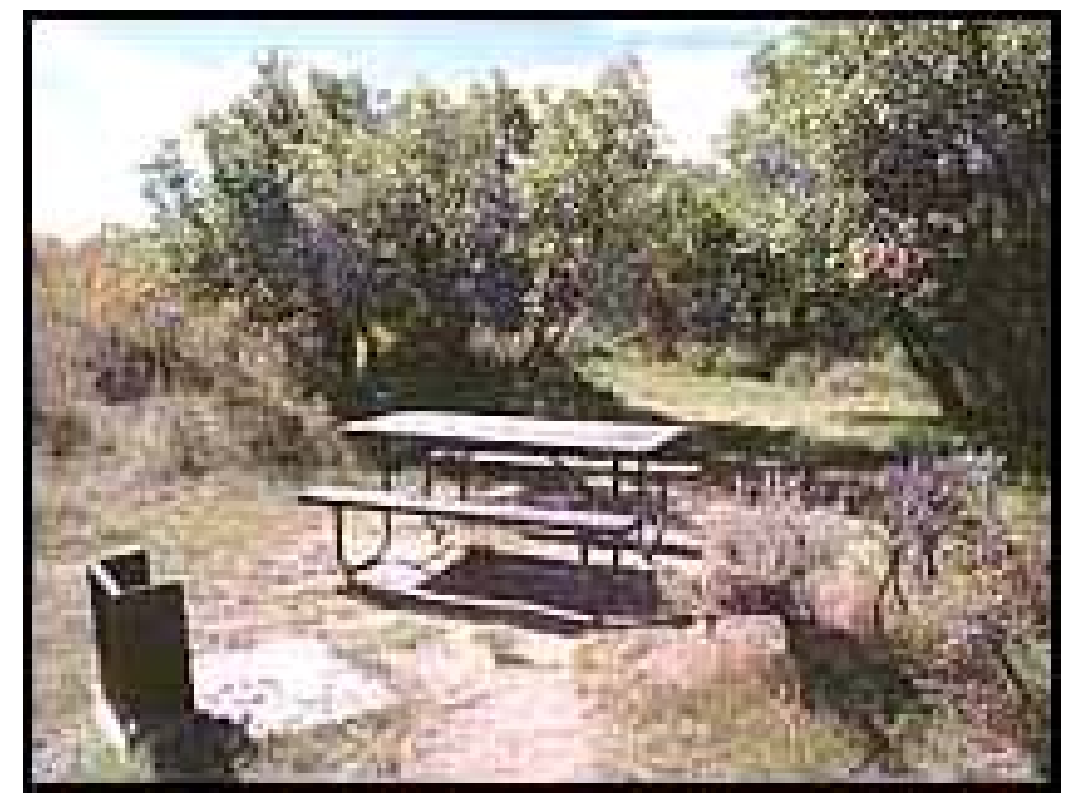

Figure 4.1. Camping at the Black Canyon of the Gunnison (Camping: Black Canyon of the Gunnison National Park 2003) 


\subsubsection{Backcountry}

A commonality between the monuments studied for this document was the allowance of backcountry campingไhiking with restrictions. Venturing into the backcountry areas of these monuments is not recommended for everyone. Campers and hikers enter the backcountry at their own risk. Because of the remote and rugged terrain common to these monuments, search and rescue efforts are lengthy and costly operations. Visitors who require search and rescue efforts, in most areas, are responsible for the costs incurred by authorities. Backcountry hiking thus is recommended only to very experienced hikers and campers. Anyone entering the backcountry should be prepared for emergencies and should have prepared emergency actions plans before their trips. Common restrictions for backcountry visitors include limits on areas in which camping is allowed and the number of hikers allowed to enter the backcountry per group. Backcountry hikers are also required in many of the monuments to obtain permits, and it is recommended that they file itineraries with the managing authority before entering the backcountry areas of the monument (Description: Grand Staircase-Escalante National Monument 2003). Itineraries include important information to officials, such as the entry/exit date for each party, the planned hiking route, and emergency contact numbers. These itineraries are used by authorities in case search and rescue efforts are needed. Hikers are also encouraged to leave a copy of their itinerary with family or friends as a safety precaution (Parks-Aniakchak National Monument and Preserve 2003).

Backcountry campers are required to pack out what they pack in; i.e., hikers are asked to leave the site as they found it. Common requirements are all waste, trash, leftover food, and litter must be packed out. This includes any toilet paper and hygiene products used for sanitary needs. Toilets should be dug away from campsites. The hole should be 6 to 8 inches deep and covered with dirt when finished. Toilet paper should be returned to camp and deposited in a trash bag. (Visitor Information 2002 and 2003; Camping and Lodging: Grand Staircase-Escalante 2002.)

\subsection{Drinking Water}

Water is a major concern for visitors at national monuments. In general, people engaging in activity require approximately 1 gallon of water per day to stay properly hydrated. This is something visitors must consider before embarking on a trip to the monuments studied in this document. Seven of the eight monuments studied do not provide water, nor do they have locations nearby in which water suitable for drinking may be obtained. Visitors must plan ahead and pack in all of their water or be prepared to properly sanitize what natural sources of water may be there. The Black Canyon of the Gunnison is the only monument that provides visitors with suitable drinking water; supplies are limited and are only available seasonally from May to October. Visitors must plan to bring their own water at all other times (Camping: Black Canyon of the Gunnison National Park 2003). The Black Canyon of the Gunnison and the Carrizo Plain National Monument also provide limited supplies of water suitable for animal consumption, mainly horses, at the campgrounds they have equipped with corrals. The Black Canyon makes this water available during the same season, May to October; at other times, it is the responsibility of animal owners to pack in the water necessary for their animals. Water is furthermore not available on the trails, which is another issue riders must take into account when planning their trips (Horseback Riding: Black Canyon of the Gunnison National Park 2003). Visitors to the Carrizo Plain must call before their trip to find out if water will be available for animal consumption. But like the Black Canyon 
of the Gunnison, water is not available on the trails; therefore, this must likewise be taken into account when riders plan their trips (Horseback Riding: Carrizo Plain National Monument 2003).

\subsection{Hiking Trails}

Of the monuments studied for this document, all permitted hiking and contained some form of trail system. The trails vary greatly in the level of development. Three of the monuments studied for this document had trails that are considered to be underdeveloped, two had a developed trail system, two had a trail system with nationally designated trails, and one monument had a trail system that combined both primitive and developed trails.

\subsubsection{Underdeveloped}

Underdeveloped trails tend to be difficult to follow and are not meant for the inexperienced hiker. For example, hiking trails in the Grand Staircase-Escalante National Monument consist mainly of paths established by continued use over the years. Entire sections routinely wash out, and it is recommended that the area not be explored without a U.S. Geological Survey (USGS) map. Most hikers generally follow along the course of the main river canyon and its immediate side canyons. Hiking through this area usually requires wading in a streambed, walking along pathways across the river benches, and making frequent water crossings (Description: Grand Staircase-Escalante National Monument 2003). The Aniakchak National Monument, like the Grand Staircase-Escalante, is also an interesting place for hikers. It is a place to be enjoyed by only the most experienced hikers. There are no formal trails within the monument or the preserve. There are also no roads anywhere in the nearly 602,000 acres. Access to the monument is limited to float plane or boat only. ${ }^{1}$ Hikers find excellent hiking conditions in the open ash and cinder fields surrounding the caldera, but there are no trails to be followed. The swift, cold Aniakchak River, and the seemingly impenetrable tundra, characterizes the remainder of the landscape. A hiker's best bet for route-finding is the path of least resistance, often an animal trail. Hikers are warned to make noise to alert wildlife of their presence (Parks-Aniakchak National Monument and Preserve 2003).

The Black Canyon of the Gunnison National Monument is unique among these five national monuments because it offers both developed and undeveloped trails. Trails in this monument are characterized into two groups - rim trails and inner-canyon routes. Rim trails are well established and range in difficulty from easy to strenuous; they follow along the canyon rim. The inner-canyon routes are undeveloped trails. They are unmarked and extremely difficult routes to the bottom of the canyon. They should only be attempted by hikers in great physical condition and by those with excellent hiking skills (Hiking: Black Canyon of the Gunnison National Park 2003).

\subsection{Developed}

Along with the Black Canyon of the Gunnison National Monument, the Carrizo Plain and the Grand Canyon-Parashant National Monuments offer developed trails for hikers. The Carrizo Plain has four

\footnotetext{
${ }^{1}$ From Printable Travel Guide, a 2003 online guide produced by the National Park Service Aniakchak National Monument (no longer publicly available).
} 
established trails. Three are less than a mile in length and offer hikers views of the monument. The fourth offers a moderate hike along a ridge and is a little longer (Hiking/Biking 2003). The Grand Canyon-Parashant National Monument has three main trails available to visitors. They range in length from 3 to 12 miles and are considered easy hiking (Access, Hiking, Maps \& Info 2003).

\subsubsection{Nationally Designated Trails}

The Cascade-Siskiyou and Upper Missouri River Breaks National Monuments both contain nationally designated trails. The Cascade-Siskiyou National Monument contains the Pacific Crest National Scenic Trail (see Figure 4.2), which is open to both hikers and horses (Pacific Crest National Scenic Trail 2002). The Upper Missouri River Breaks National Monument contains two nationally significant trails: the Lewis and Clark National Historic Trail and the Chief Joseph (Nez Perce) National Historic Trail. These trails offer views of virtually untouched geography and landscape from which Native Americans carved a living. The explorers Lewis and Clark encountered these landforms on the westward leg of their journey (Upper Missouri River Breaks 2003a).

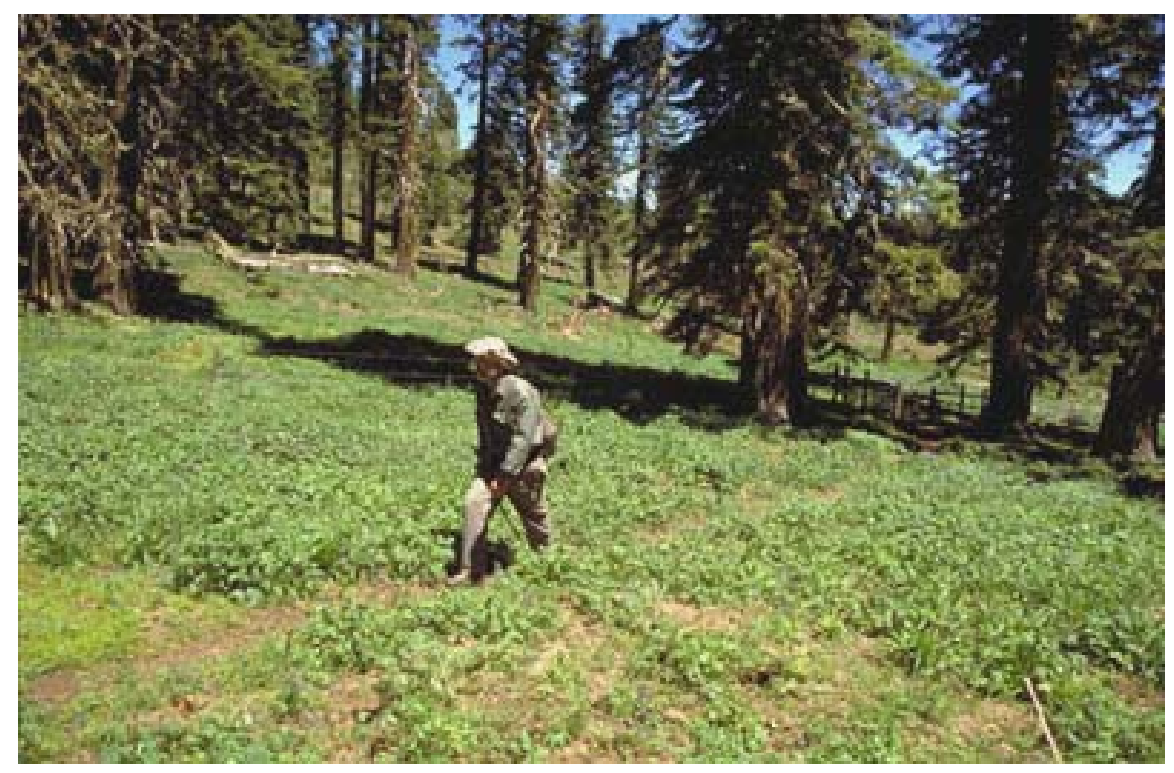

Figure 4.2. Hiking on the Pacific Crest National Scenic Trail (Pacific Crest National Scenic Trail 2002)

\subsection{Equestrian Trails}

Horseback riding is a permitted recreational activity (Figure 4.3) in at least four of the monuments studied for this document: the Cascade-Siskiyou, the Black Canyon of the Gunnison (Horseback Riding: Black Canyon of the Gunnison National Park 2003), the Carrizo Plain, and the Grand Staircase-Escalante National Monuments. Restrictions are placed on horseback riders in all four of these monuments. These restrictions include limits on where horses are permitted and on the number of horses and riders allowed in a group. For example, the Cascade-Siskiyou National Monument limits horseback riders to the Pacific Crest Scenic Trail only, whereas the Carrizo Plain limits the size of each group to no more than 20 riders (Pacific Crest National Scenic Trail 2002). The Carrizo Plain National Monument also requires riders to 
obtain a permit before entering the monument on horseback (Horseback Riding: Carrizo Plain National Monument 2003).

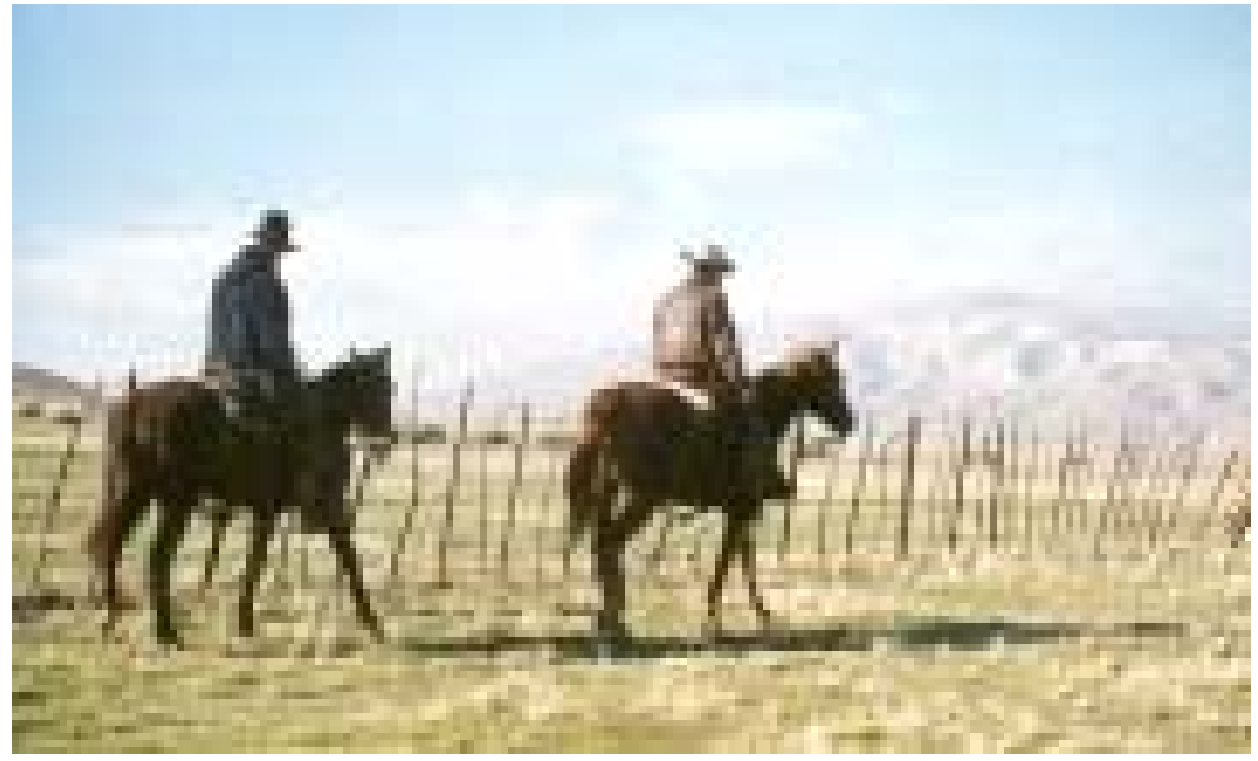

Figure 4.3. Horseback Riding

The Black Canyon of the Gunnison and the Carrizo Plain National Monument provide horseback riders with campgrounds equipped with corrals and sometimes water troughs. At the Black Canyon of the Gunnison, water is available seasonally for horses (May to October), but at the Carrizo Plain National Monument, water is not always provided regardless of the season. Horseback riders must call the area office to find out if water will be available or whether they will need to pack in their own supply (Horseback Riding: Black Canyon of the Gunnison National Park 2003; Horseback Riding: Carrizo Plain National Monument 2003).

The degree of difficulty in the trail terrain varies on each monument. The Grand Staircase-Escalante National Monument, for example, has trails suitable for all skill levels. Trails range from unique and scenic, 1-day rides to more rugged trails that can take up to 3 days to ride. The trails into the backcountry are the most rugged and primitive and are mostly unmarked routes. Riders are recommended to choose routes based on their riding skill, the horse's trail experience, and the horse's ability to traverse difficult terrain (Horseback Riding Routes 2002). The Black Canyon of the Gunnison likewise has three trails ranging from 4 to 5 miles in length that permit horses. The trails range from a moderately strenuous terrain to an unmaintained trail (Horseback Riding: Black Canyon of the Gunnison National Park 2003). In all monuments, it is the rider's responsibility to be aware of the regulations established by the managing authority and to take the necessary safety precautions to protect themselves and the monument.

\subsection{Mountain Biking Trails}

Mountain biking has become an increasingly popular recreational activity in the last few years. In the eight monuments studied for this document, at least four considered mountain biking an acceptable 
recreational activity and permitted it, with restrictions, on the monuments. These four monuments are the Cascade-Siskiyou, Carrizo Plain, Agua Fria, and Grand Staircase-Escalante National Monuments. The most common restriction for mountain bikers in these monuments is where bicycles are permitted. In most, bicycles are limited to designated or existing roads. In the Cascade-Siskiyou National Monument for example, bicycles are limited to just a few existing roads, and they are prohibited from others such as the Schoheim Road. Bicycles are also prohibited on trails and from cross-country travel to protect natural resources (Visitors Information 2002). The Carrizo Plain National Monument also limits bicycles to existing roads only and also prohibits them from existing trails (Hiking/Biking 2003). On the other hand, the Grand Staircase-Escalante National Monument is unique in its attitude toward mountain bikers. The Grand Staircase-Escalante considers mountain bikers to be a refreshing way to discover the landscapes the monument has to offer and, as such, permits bicycles to traverse the several hundred miles of roads and trails in the monument (Mountain Biking Tours 2002).

\subsection{Fishing}

Fishing is permitted in the seven of the national monuments studied in this document where there was some source of year-round water. This water is primarily found in the form of a river, but in at least two monuments there are lakes. In general the designation of a national monument has not had an affect on fishing in these seven monuments. In these monuments, fishing tends to be managed by the appropriate state's Department of Fish and Wildlife and is consistent with state regulations (Frequently Asked Questions 2002; Agua Fria National Monument Fact Sheet 2003). Fishing licenses are thus still typically required (Parks-Aniakchak National Monument and Preserve 2003). Restrictions on fishing are common. For example, the Black Canyon of the Gunnison National Monument limits the number and size of fish that may be kept as well as strictly forbidding the catch of other species. At the Black Canyon of the Gunnison, anglers must return any brown trout 12 to 16 inches long to the water, rainbow trout are strictly catch and release, and anglers are allowed only four fish 12 inches or smaller or 1 fish 16 inches or longer (Fishing: Black Canyon of the Gunnison National Park 2003).

\subsection{Hunting}

In the monuments studied for this document, hunting tends to be an allowed recreational activity that in most cases has not been affected by the designation of a national monument. Hunting is allowed in all monuments studied for this document. It is typically regulated by the appropriate state's Department of Fish and Wildlife, and like fishing is managed consistent with state regulations. Hunters are required to obtain permits (Parks-Aniakchak National Monument and Preserve 2003; Frequently Asked Questions 2002). The monuments, because of the unique landscapes they are designed to protect, tended to share some common restrictions. For example, hunting is not allowed near campgrounds, management facilities, and areas that are restricted or prohibited in order to protect objects contained in them (Hunting 2003; Agua Fria National Monument Fact Sheet 2003).

\subsection{Visitors Facilities}

Of the eight monuments studied and compared for this document, only two had visitor centers located on or near the monument: Carrizo Plain and the Black Canyon of the Gunnison. The Carrizo Plain National 
Monument Visitors Center is the Goodwin Educational Center; it serves as an information center for the monument, and it offers displays and exhibits explaining the uniqueness of the monument and

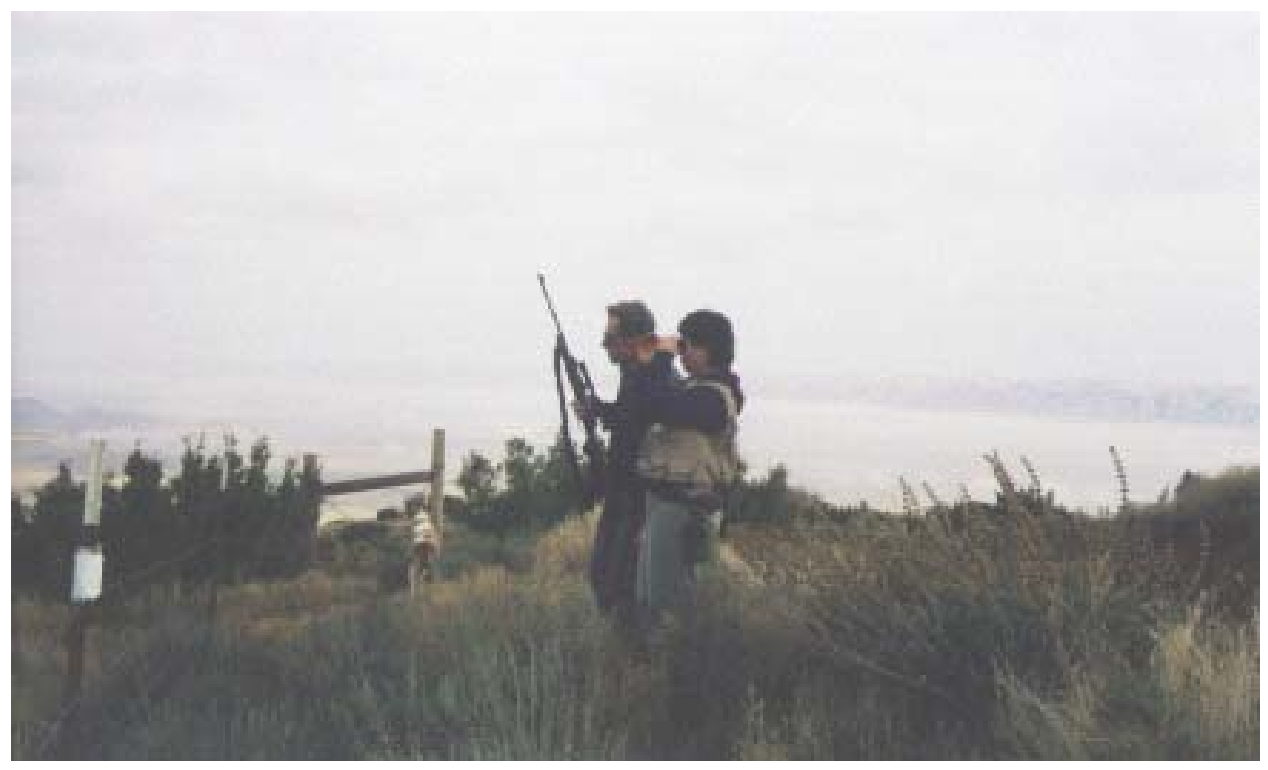

Figure 4.4. Hunting on the Carrizo Plain National Monument (Hunting 2003)

surrounding areas (Goodwin Education Center 2003). The Black Canyon of the Gunnison maintains a year-round visitor's center on its south rim. It serves as an information center for visitors where they may pick up maps and other aids as well as view interactive exhibits about the monument (Black Canyon of the Gunnison National Park 2003a). The remaining six monuments either have visitor's centers in the planning stages, or they have chosen not to build one. Information on their monuments typically available from a visitor's center may be gathered from the managing agency area office.

\subsection{Safety}

Because of the untouched, remote, and undeveloped nature that characterizes national monuments, the safety of visitors is of major concern. Visitors entering national monuments need to be prepared and aware of the dangers they may encounter. Of the eight national monuments studied in this document, the potential hazards visitors may face vary greatly, but all of the monuments shared at least three safety issues: weather, road conditions, and wildlife.

\subsubsection{Weather}

The remote nature of these monuments makes the weather a serious safety concern for visitors. In monuments such as the Grand Staircase-Escalante, Agua Fria, and the Grand Canyon-Parashant, temperatures during the summer months can easily, and frequently do, exceed $100^{\circ} \mathrm{F}$. Visitors to these monuments need to carry an adequate supply of water for each person. During hot-weather travel, an adequate supply of water means at least 1 gallon of water per person, per day (Camping and Lodging: Grand Staircase-Escalante National Monument 2002; Agua Fria National Monument Fact Sheet 2003). 
In the Grand Staircase-Escalante, flash flooding and lightening storms are also a concern during the rainy season (July to September). Hikers must be cautious during these months, and they are warned to avoid entering narrow canyons when storms are approaching (Things You Need to Know 2002). On the other extreme is the Aniakchak National Monument, which is known for its notoriously cold weather. Summer highs in this remote part of Alaska average in the high 40s to low 50s. Most days are cloudy and wet with frequent high winds. Conditions like these can quickly lead to hypothermia, a major concern for visitors. Visitors are cautioned to know the signs of hypothermia and how to treat it; but more importantly, to prevent it. Weather conditions can also prevent or delay drop-offs and pick-ups. Visitors are counseled to prepare themselves for the worst (Parks-Aniakchak National Monument and Preserve 2003).

\subsubsection{Road Condition}

Road conditions are another area of concern for monument visitors. Often, those conditions and bad weather combine to create very dangerous situations. In most of the monuments studied for this document, many of the roads leading to and across the monuments tend to be dirt and unimproved. This makes these roads very rugged and in many places impassible during certain times of the year. Take the Carrizo Plain National Monument, for example: During the rainy season, typically the winter months, dirt roads become very slick and impassible. This eliminates access to most trails. Visitors are instructed to carry spare tires, extra food and water, and warm clothes during this time as a safety precaution. Visitors are also encouraged to check with the visitor's center to find out which roads are safe to travel and which are closed (Goodwin Education Center 2003). Similarly, wet conditions make roads in the Grand Staircase-Escalante (Figure 4.5), Grand Canyon-Parashant, and Agua Fria National Monuments impassible during certain times of the year. Visitors are encouraged to check with information centers to get current road conditions and to always carry a spare tire, extra gas, water, and food (Agua Fria National Monument Fact Sheet 2003; Grand Canyon-Parashant National Monument Fact Sheet 2003). 


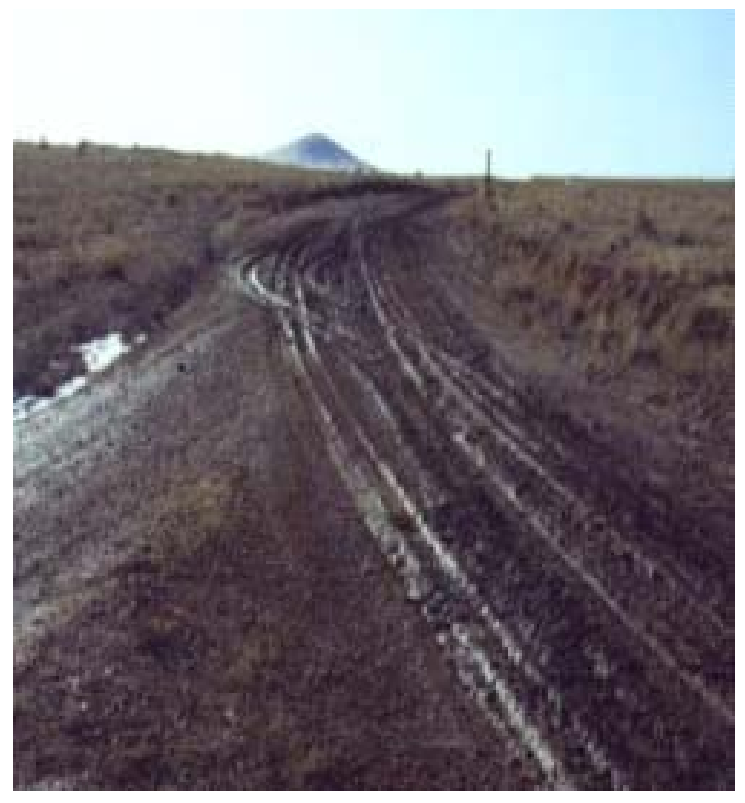

Figure 4.5. Road Conditions on the Grand Staircase-Escalante National Monument (Grand StaircaseEscalante National Monument Road Conditions 2002)

\subsubsection{Wildlife}

Wildlife is yet another concern for visitors. Visitors entering national monuments in many cases are excited to see the wildlife that inhabits these lands. But it is important that visitors keep a respectful distance from wild animals and be aware of the issues specific to each monument. For example, visitors to the Black Canyon of the Gunnison National Monument (Black Canyon of the Gunnison National Park 2003a) are advised to never disrupt, approach, or attempt to feed wild animals. Visitors are further encouraged not to approach denning sites and to back away from any animal that seems stressed, agitated, or angry. Animals are sensitive to situations that may jeopardize or be detrimental to the survival of their young (Wildlife Watching 2003). In the Grand Canyon-Parashant National Monument, on the other hand, wildlife safety issues focus particularly on rodents and rabbits because they may carry diseases such as rabies, hantavirus, or the plague, and they may transmit them to humans (Visitors Information 2003). In other monuments, such as the Upper Missouri and Agua Fria National Monuments, poisonous snakes are of particular concern. Visitors are warned to be careful of where they put their feet and hands as they are exploring these beautiful lands (Planning a Trip of the River 2002; Agua Fria National Monument Fact Sheet 2003). 


\subsection{Hanford Reach National Monument}

\subsection{Uniqueness of the Hanford Reach National Monument}

The Hanford Site's past mission as one of DOE's nuclear reservations involved in plutonium production and nuclear weapons research makes the Hanford Reach National Monument particularly unique in comparison to the eight other monuments studied for this document. In 1989, when Hanford's production mission ended, its cleanup mission began, and the following defines successful cleanup of the Site:

Successful Hanford cleanup will mean eliminating a major threat to human health and the environment. It will mean permanent protection of the groundwater and the Columbia River. It will mean freeing up large stretches of land — much of it along the Columbia River shoreline and part of the Hanford Reach National Monument-for conservation, Tribal, recreational, and industrial uses. It will mean the end of DOE's EM cleanup mission at Hanford and a major taxpayer liability—currently around \$2 billion per year (DOE/RL 2003).

The cleanup mission is expected to be completed by 2035 or earlier. Before then, as portions of the site are cleaned up to approved levels, they will be transitioned to the USFWS, or other appropriate agencies, and opened for other uses, including recreation (DOE/RL 2003). Currently, visitors may access over 57,000 of the 195,000 acres the Hanford Reach National Monument encompasses (Having Fun on the Monument 2002). The areas open to visitors include parts of the Columbia River Corridor, all of the Columbia River's surface water, the McGee Ranch and Riverlands, Vernita Bridge, and the Wahluke Slope (Regulations 2002). By 2005, it is expected that nearly all of the Fitzner/Eberhardt Arid Lands Ecology Reserve, all of the Wahluke Slope, and the Riverlands will be ready for transfer, and by 2012, approximately $210 \mathrm{mi}^{2}$ of the Columbia River Corridor will have been cleaned to a level suitable for residential use (DOE/RL 2003). When cleanup is completed, it is expected that the Hanford Site will have shrunk as depicted in Figure 5.1.

It is expected that some level of ongoing activity will remain in the Central Plateau area (the Core Zone) after cleanup is completed (see Figure 5.1). Ongoing activity in the Core Zone may include the following:

- continued commercial waste operations

- U.S. Navy’s disposal of decommissioned naval reactor compartments

- stewardship of waste

- possible ongoing DOE waste disposal operations

- ongoing groundwater monitoring (DOE/RL 2003). 


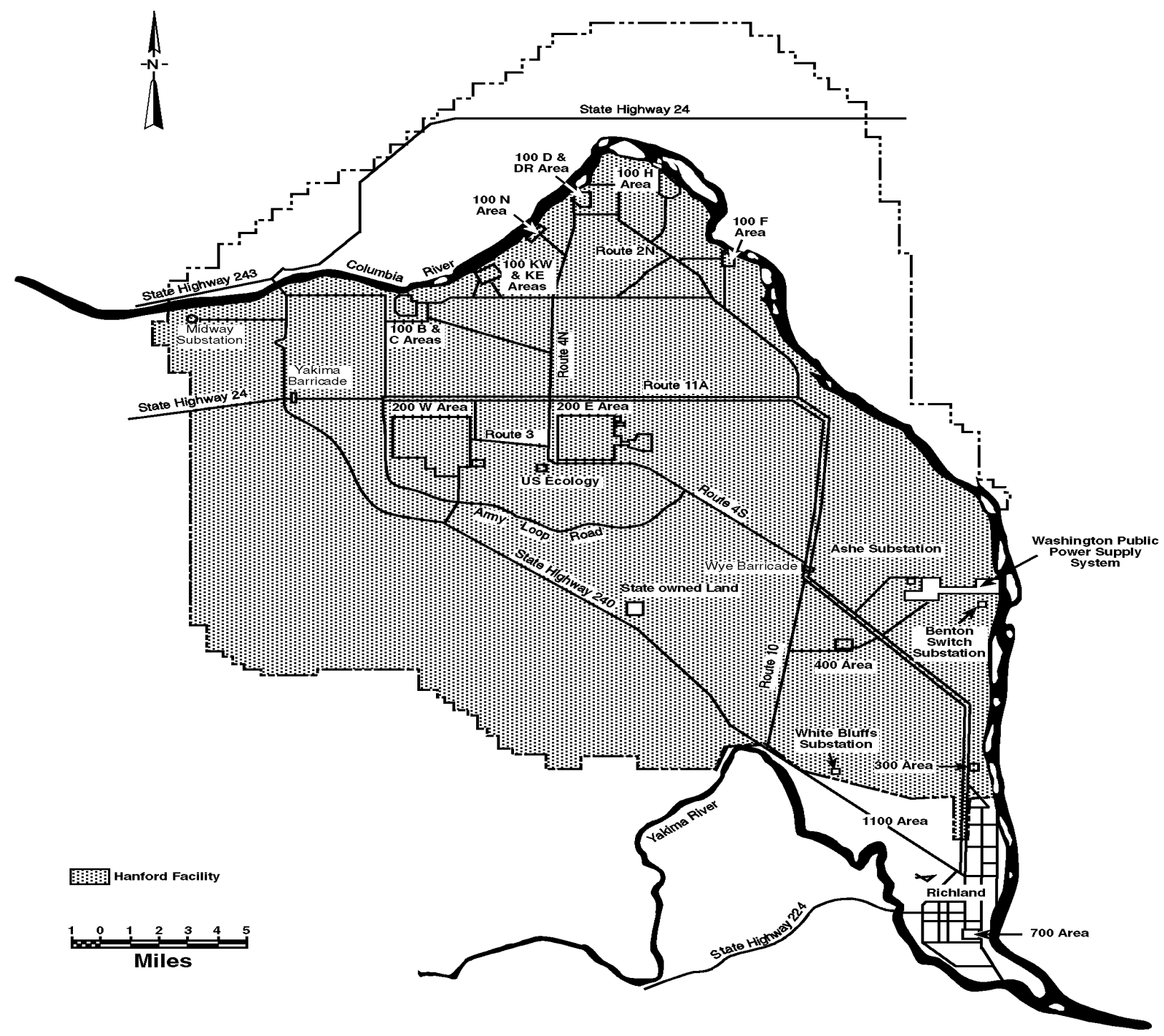

H97020271.1

Figure 5.1. Map of the Hanford Reach Depicting the Shrinking of the Hanford Site and Marking the Locations of the Units of the Hanford Reach National Monument (DOE/RL 2003)

\subsection{Currently Permitted Recreational Activities}

Visitors to the monument have limited opportunities available to them at this time. Recreational opportunities are limited to wildlife-dependent activities such as hunting, fishing, photography, and wildlife observation (Having Fun on the Monument 2002). Visitors may use the Columbia River; motorized and non-motorized boating is permitted year-round. Visitors should be aware of the monument's current condition and prepare accordingly. There is minimal signage on the monument and very primitive facilities. Visitors must also be careful to only go into properly designated areas. Visitors 
are not permitted on the Fitzner/Eberhardt Arid Lands Ecology Reserve or the Saddle Mountain Wildlife Refuge, as well as a number of other areas currently under the DOE's control (Having Fun on the Monument 2002). The units visitors are permitted to enter are open primarily to day-use activities only.

The Columbia River Corridor and the river's surface water support a number of recreational activities such as boating, fishing, and hunting. Boaters may access the river from a number of launches located downstream of the monument in the Tri-Cities, or they may use one of a few located on the monument (Facilities: Hanford Reach National Monument 2002). The Vernita Bridge unit is primarily used as a boat-launching location. The 800 -acre area's primary use is as an access to the river and a location for bank fishing. The Hanford Reach contains the largest spawning habitat for Chinook salmon on the Columbia River. The river supports a number of other species of fish, including redside shiners, carp, largescale sucker, northern pike minnow, peamouth, and several species of bass and sturgeon (Vernita Bridge Unit 2002). The McGee Ranch and Riverlands unit offer much of the same recreational activities as the Vernita Bridge and Columbia River Corridor units. Visitors may launch boats from an undeveloped cobblestone ramp, or they may fish from the banks (McGee Ranch/Riverlands Unit 2002).

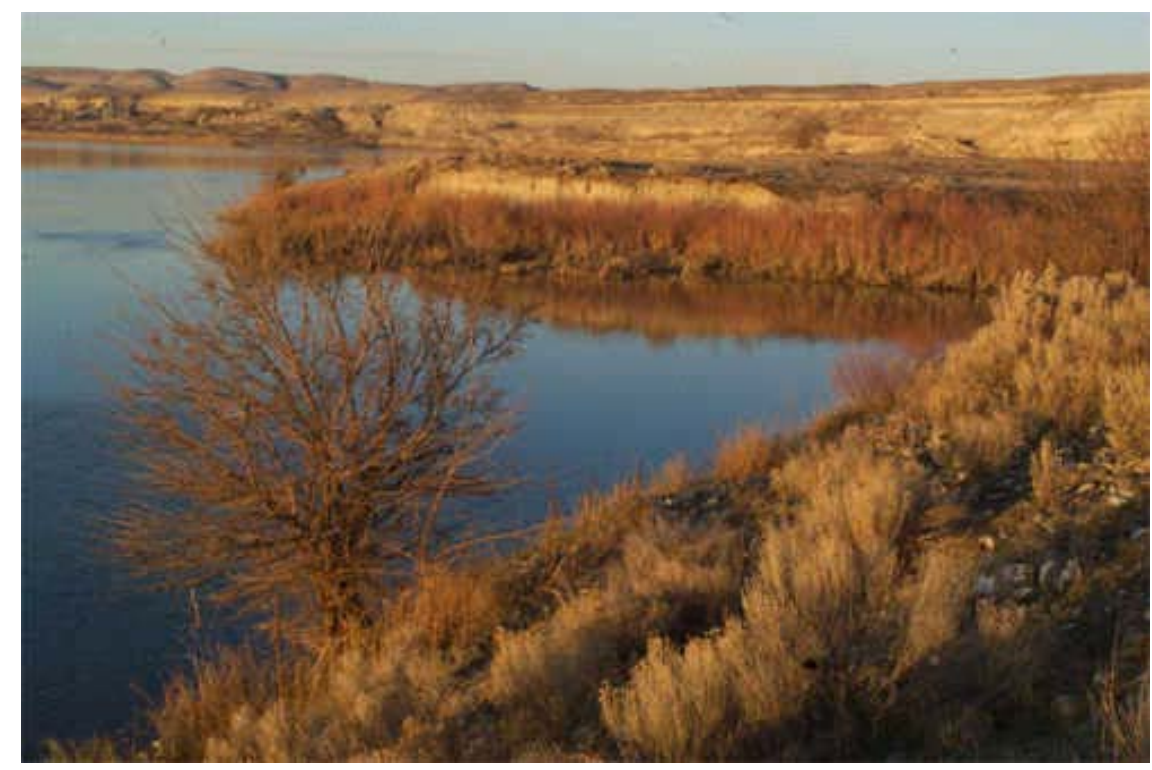

Figure 5.2. A View of the Columbia River on the Hanford Reach National Monument (Wildlife and Environmental Studies 2003)

The Wahluke Unit provides visitors with river access at the White Bluffs boat launch, but the unit also supports a number of other recreational activities, including hunting, hiking, wildlife observation, and photography. Visitors are also permitted to use motorized vehicles and bicycles on designated roads in this unit. This unit also contains "a scenic overlook and parking area with walking access to Wahluke Lake” (Wahluke Unit 2002). 


\subsection{The Future}

Many different scenarios have been envisioned for what may be permitted on the Hanford Reach National Monument in the years after cleanup has been completed. It is expected that $210 \mathrm{mi}^{2}$ of the River Corridor, of which a part is a portion of the Hanford Reach National Monument, will be cleaned up to approved levels. All waste sites will be removed and backfilled, all extra buildings will be removed, eight remaining reactors will be cocooned for long-term storage, and the River Corridor may be deleted from the U.S. Environmental Protection Agency's National Priorities List. Once that is completed, the land surfaces in what is known as the 100 Area will be cleaned up to a level suitable for residential use, and the area known as the 300 Area will be suitable for industrial use. These scenarios include an increased presence of visitors to this area. It is envisioned that the monument will allow overnight recreational use. Further use of the Columbia River is also envisioned. Through science and technology, DOE is also trying to develop the means to protect the groundwater at the site, and investigating whether the water is safe for human consumption. It is also envisioned that the monument will contain a museum: there is interest in recognizing Hanford's scientific and engineering feats and its unique role in defending our nation by turning Hanford's first reactor, the B Reactor (Figure 5.3), into a museum (DOE/RL 2003).

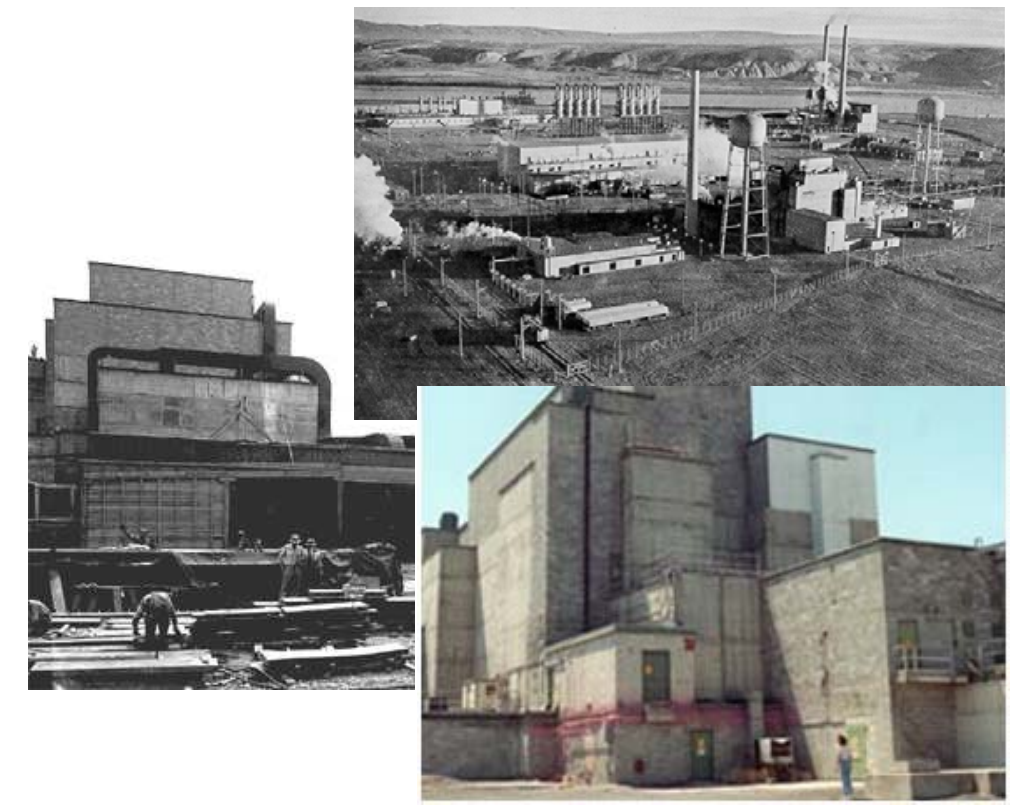

Figure 5.3. The B Reactor. Left: The B Reactor During Construction. Top Right: The B Reactor During Active Use. Bottom Right: The B Reactor Today (Hanford Engineer Works 2003; BRMA Vision Statement for a B Reactor Museum, Park, and Cultural Preserve 2003). 


\subsection{Assumptions and Conclusions}

The purpose of this document was to compare recreational land uses common to eight national monuments with characteristics in common with the Hanford Reach National Monument and apply those findings to what land uses are currently permitted on the monument, as well as what the future may hold for the monument. This section will discuss recommendations of what recreational land uses should be permitted based on the comparison of the eight national monuments studied.

\subsubsection{Camping}

In all of the monuments studied in this document, camping, either in primitive or developed settings, was allowed. The level of development found at each monument varied greatly, but regardless of whether no developed sites were offered (like the Aniakchak National Monument) or whether primarily developed sites were offered (like the Black Canyon of the Gunnison National Monument), camping was a permitted recreational activity. In addition, the eight monuments studied shared in common an allowance of backcountry camping. Taking that into consideration, camping should be a permitted activity on the Hanford Reach National Monument. Camping should be limited to primarily primitive-style sites (with very few developments added) to preserve the untouched condition of the land. Sites may contain a fire pit and perhaps a picnic table. Also, the USFWS should consider providing portable toilets at campgrounds. Portable toilets would eliminate the need to dig "cat holes" that would damage the fragile environment. Campsites should be located in areas that receive the most visitors to eliminate any unnecessary land development. These areas are predominately around the boat launches in the Vernita Bridge and Wahluke Slope Units. Also located in the Wahluke Slope Unit is the Wahluke Lake Pond. This area may serve as an ideal area to locate a campground as well. The Vernita Bridge Unit may be an appropriate area to consider locating a more developed campsite, such as one that would accommodate the use of a recreational vehicle, if it is determined that campsites are needed. The Vernita Bridge Unit is located just off Highway 240, which would provide visitors with access to the area and make it a more attractive location for a campground.

Because of the unique history of the Hanford Reach National Monument and the Hanford Site, camping in any form—primitive or developed—will be permitted with restrictions if allowed. These restrictions will be unique in comparison to the eight monuments studied for this document because of DOE's ongoing environmental cleanup mission. Camping, if permitted, will most likely be limited to the Columbia River's north shore, mainly in the Vernita Bridge, Saddle Mountain, and Wahluke Slope Units for at least the next 9 years or until the Columbia River Corridor is ready for transition in 2012. However, because of DOE's cleanup efforts, there may be reservations about opening up the south shore for overnight use, even after the River Corridor is ready to be transitioned. Another possible restriction may be any permit that may be required. Requiring visitors to obtain a free or purchased permit to camp at the monument would allow the USFWS to track who visits the monument and what areas tend to be the most popular. This information may be useful to the USFWS; they could maintain an accurate count of how many visitors participated in camping activities on the monument, which would provide them with accurate data when planning future improvements. A permit may also serve as a waiver for the USFWS, 
releasing them from any liability as a result of possible harm visitors may incur in the undeveloped, natural environment that characterizes this monument.

\subsubsection{Hiking Trails}

Of the eight monuments studied, all permitted hiking. The development and condition of the trail systems on these monuments varied greatly between the eight. In some of the monuments studied, such as in the Aniakchak National Monument, the trail system was considered to be underdeveloped, while other monuments maintained more developed trail systems. In addition, two monuments studied, the Cascade-Siskiyou and the Upper Missouri River Breaks National Monuments, contain nationally designated trails.

Currently on the Hanford Reach National Monument, hiking is permitted but is limited to the Wahluke Slope Unit, where a few trails exist for cross-country hiking. Trails are limited primarily to old roads (General Public Use 2003). Taking this into consideration, and applying what was found at other national monuments, it is recommended the Hanford Reach National Monument broaden its trail system. The level of development and maintenance of the trail system is perhaps the biggest question left to be answered.

In keeping with the untouched nature of the monument and its history, it would be appropriate to design a trail system that would be considered "underdeveloped"; i.e., the land should be disturbed as little as possible to preserve the ecosystem the monument was designed to protect. Existing trails and old roads could be modified to lengthen their route or alter their direction. When modifying existing trails or developing new ones, the USFWS should consider where monument visitors are more likely to visit. For instance, areas along the shoreline may be more attractive to visitors and therefore be more popular. Trails along the shoreline would provide monument visitors with easy access to a trail as well as beautiful views of a unique stretch of the Columbia River; however, there are currently no trails that follow along the river. Trails in the Wahluke Slope Unit could be modified by lengthening them so that they would follow along the Columbia River shoreline, or a new trail could be designed that would follow the river's path.

In 2005 when the Fitzner/Eberhardt Arid Lands Ecology Reserve and the Saddle Mountain Wildlife Refuge are transitioned from DOE control to the USFWS, it will have to be decided how much human contact will be permitted in these areas. Currently, public use is prohibited. These units are used for environmental education and ecological research activities; only individuals who have received approval from the proper authorities are allowed to enter these units. When the land is transitioned, it will be necessary to determine the level of public use that will be permitted on these units. If it is determined that they should be opened for public use, such as hiking, the trails should be limited in number and be designated as underdeveloped trails to preserve as much as possible the unique value of these units while allowing visitors to experience them as well.

In 2012 when it is expected that the Columbia River Corridor will be cleaned to an approved level and will be ready for transition, the USFWS will have to decide what trails will be permitted. With DOE's ongoing environmental cleanup mission, there will be issues regarding both human safety and security that will be necessary to address before a final decision can be made. Because of these unique issues 
surrounding the south shoreline of the River Corridor, it may be appropriate to design a more "developed" trail system along this side of the shoreline. A developed trail would help ensure that people would stay on the designated path and thus keep them out of inappropriate areas.

\subsubsection{Equestrian Trails}

In the eight monuments studied for this document, at least four permitted visitors to ride horses on the monuments. There were various restrictions placed on horses and their riders, such as the number of riders allowed in a party or limits to the area and trails on which they are allowed to ride. Some monuments, such as the Black Canyon of the Gunnison and the Carrizo Plain National Monuments offered riders certain perks, such as campgrounds equipped with corrals. But a commonality between the four national monuments that permitted horseback riding was the rugged, primitive nature of the trails.

Currently on the Hanford Reach National Monument, horseback riding is permitted, but like hiking, it is limited to the Wahluke Slope Unit. Horses are permitted on the old roads, which serve as the trail system. Horseback riding should continue to be a permitted recreational activity at the monument. Like hiking trails, horseback riding trails should continue to be made up of underdeveloped, primitive, and rugged trails. An issue that must be addressed is where horseback riders will be permitted. Currently, hikers and horseback riders share the same trails, which is not always agreeable. If more trails are developed, horseback riders should be limited to a few designated trails, thus alleviating those issues. Another issue will need to be addressed alongside hiking: whether horses will be permitted in the Arid Lands Ecology Reserve or the Saddle Mountain Wildlife Refuge when these units are transitioned in 2 years. One positive difference between horseback riders and hikers is that horseback riders may not disturb these units as much as hikers, and are less likely to disturb areas that are unsafe. Horseback riders tend to stay on their horses and on the trail, whereas hikers can wander off designated trails and into areas that may be inappropriate or unsafe.

In the eight monuments studied for this document, four of them permitted mountain biking on certain designated trails or roads. The Cascade-Siskiyou National Monument, for example, permits mountain biking on a few existing roads in the monument and prohibits them from existing trails. The Grand Staircase-Escalante National Monument, on the other hand, permits mountain bikes on all roads and trails throughout the monument.

Currently, the Hanford Reach National Monument permits mountain bikes on existing roads. The Hanford Reach National Monument considers mountain bikes to be vehicles and thus requires them to follow all federal statutes and posted restrictions. Off-road mountain biking is strictly prohibited. Mountain biking should continue to be a permitted recreational activity at the monument in current restricted areas where bikes are permitted. These restrictions protect the fragile environment that characterizes the Hanford Reach National Monument and thus should be maintained.

\subsubsection{Hunting and Fishing}

In all eight national monuments studied for this document, hunting is a permitted recreational activity. Hunting is regulated by the appropriate state's Department of Fish and Wildlife and is managed consistent with state regulations. Fishing is likewise a permitted recreational activity in all monuments that 
contained a body of water (lake or river) that supports fishing. Like hunting, fishing is also typically managed by the appropriate state's Department of Fish and Wildlife consistent with state regulations. The USFWS permits both hunting and fishing at the Hanford Reach National Monument. Fishing is managed consistent with state regulations, and information is provided in the 2004-2005 Fishing in Washington Rule Pamphlet (USFWS 2004a). Hunting is limited to the Game Management Unit located in the Wahluke Slope Unit. Hunting is managed consistent with state regulations, and information may be found in the 2004-2005 Washington State Big Game Hunting Season and Rules Pamphlet (USFWS 2004b) for specific regulations and Game Management Unit information (General Public Use 2003).

\subsubsection{Visitors Center}

There are no facilities, including no visitor center, on the Hanford Reach National Monument. Since the monument was announced, there has been interest in turning Hanford's first reactor, the B Reactor, into a museum and a visitor's center. As a museum, the B Reactor would contain exhibits that would "address the natural and cultural history of the Hanford Site, the Hanford Reach of the Columbia River, and the construction and development of Hanford and the Manhattan Project" (BRMA Vision Statement for a B Reactor Museum, Park, and Cultural Preserve 2003). In 1992, the National Park Service entered the B Reactor into the National Register of Historic Places, thus recognizing its historical significance and preserving it for future uses. The B Reactor was the first full-size functioning reactor completed on the Hanford Site. The reactor produced plutonium used in the first nuclear explosion—-the Trinity Test in New Mexico-and the second atomic bomb dropped on Nagasaki, which was credited with bringing about the final surrender of Japan. Plutonium production at the B Reactor ended in 1968 when the reactor was decommissioned. Currently, the reactor serves as a controlled access museum managed by DOE, though no tours have been allowed since September 11, 2001, because of increased security concerns (BRMA Vision Statement for a B Reactor Museum, Park, and Cultural Preserve 2003).

Visitor centers are not commonly found at national monuments. In the eight monuments studied for this document, only two contained visitor centers. However, turning the B Reactor into a museum and a visitor's center is an excellent idea. The unique history that has characterized and defined this area requires a unique way to communicate this history to visitors. The B Reactor would provide a forum to explain Hanford's historical impact to our nation and its role in preserving the Hanford Reach for the past 60 years. By turning the reactor into a museum, one of the original structures built on the Hanford Site would be preserved for future generations, and by making it a visitors center, people will not only be able to experience a little of the history that has made this area unique, but will also be able to gather information on the monument and learn about its unique qualities. However, if the B Reactor were converted into a museum, the USFWS would not run or manage it because the museum would not be a mission goal of the USFWS. If B Reactor is converted into a museum, the National Park Service would most likely manage it.

In addition to what is being proposed for the B Reactor, the USFWS recently entered into a partnership with the Friends of the Hanford Reach National Monument; the Columbia River Exhibition of History, Science, and Technology (CREHST); the Tri-Cities Visitors and Convention Bureau; and various Tribal partners to officially dedicate 50 acres of land in south Richland for the new Hanford Reach National Monument Heritage and Visitor Center. The Center will be located at Columbia Point South at the confluence of the Yakima and Columbia Rivers. It will contain an exhibition gallery, as well as a number 
of other amenities, and it is expected to become a significant visitor's attraction in the area (Site Dedication for Monument Interpretive Center 2002).

\subsubsection{Drinking Water}

Drinking water is a major issue driving the cleanup mission on the Hanford Site and the monument, and is also a major concern in developing a management plan for the monument.

An interesting commonality exists among the eight monuments studied for this document. Only one, the Black Canyon of the Gunnison, provided visitors with safe drinking water, and then only seasonally. Furthermore, the water was not from onsite; it was brought from another location. At the remaining seven national monuments, it was the responsibility of visitors to carry in their own supply of drinking water. Applying this observation to the issues surrounding the Hanford Reach National Monument, it is recommended that the USFWS need not feel obligated to provide visitors with drinking water from onsite. Water could be brought in seasonally if desired, as in the Black Canyon of the Gunnison, but it would also be acceptable for the USFWS to require visitors to carry in their own supplies of safe drinking water.

For the past 50 years, the lands that make up the Hanford Reach National Monument have been allowed to develop naturally, untouched by man. Preserved by undisputedly unusual circumstances, this magnificent area has preserved an irreplaceable natural and historic legacy. Now as its past comes to a close, and its future is yet to come, plans for what that future holds are being developed and discussed. The unique history that characterizes the Hanford Site's past has created a number of distinct challenges that must be addressed before an effective management plan may be developed and the future of the monument determined. Issues surrounding the Hanford Site's environmental cleanup mission must be addressed, solutions must be found, and threats to human health and the environment must be eliminated. The groundwater, as well as the Columbia River, must be protected from further contamination, and the monument in its entirety must be transitioned to its long-term stewards. The nature of these challenges is unique, with complex issues that must be dealt with. However, the Hanford Reach is not alone in facing challenges; many other national monuments have faced seemingly insurmountable issues, but through sound planning, solutions were found. Efforts are well underway to do likewise on the monument. Currently, the USFWS plans to release its Comprehensive Conservation Plan sometime next year. The plan will detail the management of the monument as well as set forth the means by which future generations will be permitted to learn, discover, explore, and experience the rich history of the Hanford Reach now and for years to come. 


\subsection{References}

Access, Hiking, Maps \& Info. 2003. Grand Canyon-Parashant National Monument. Sierra Club:

Arizona's Five New National Monuments. Retrieved on September 8, 2003.

Available URL: http://arizona.sierraclub.org/monuments/parashant/parashant-rec.html.

Agua Fria National Monument Fact Sheet. 2003. Bureau of Land Management Arizona State Office. Last update 12 September 2003; retrieved 8 September 2003.

Available URL: http://azwww.az.blm.gov/aguafria/afriafactsht.htm.

American Antiquities Act of 1906. 16 USC 431-433. National Park Service. U.S. Department of the Interior. Retrieved 4 April 2004. Available URL: http://www.cr.nps.gov/local-law/anti1906.htm.

Aniakchak National Monument and Preserve. 2003a. National Park Service. U.S. Department of the Interior. Last update 12 September 2003; retrieved 8 September 2003.

Available URL: http://www.nps.gov/ania.

Aniakchak National Monument and Preserve. 2003b. Recreation.gov. Last update 30 June 2003; retrieved 23 September 2003. Available URL: http://www.recreation.gov/detail.cfm?ID=2567.

Black Canyon of the Gunnison National Park. 2003a. National Parks Service. U.S. Department of the Interior. Retrieved 28 April 2004. Available URL: http://www.nps.gov/blca.

Black Canyon of the Gunnison National Park. 2003b. Recreation.gov. Last update 30 June 2003; retrieved 23 September 2003. Available URL: http://www.recreation.gov/detail.cfm?ID=2592.

BRMA Vision Statement for a B Reactor Museum, Park, and Cultural Preserve. 2003. B Reactor Museum Association. Last update October 2003; retrieved October 2003.

Available URL: http://b-reactor.org/vision.htm.

Camping and Lodging: Grand Staircase-Escalante National Monument. 2002. Desert USA. Retrieved 2 September 2003. Available URL: http://www.desertusa.com/escalante/du_esc_camp.html.

Camping: Carrizo Plain National Monument. 2003. Bureau of Land Management Bakersfield Field Office. Last update 2 May 2003; retrieved 8 September 2003.

Available URL: http://www.ca.blm.gov/bakersfield/campingcpna.html.

Camping: Black Canyon of the Gunnison National Park. 2003. National Park Service. Last update 16 September 2003; retrieved 8 September 2003.

Available URL: http://www.nps.gov/blca/webvc/camp.htm.

Carrizo Plain National Monument. 2003. Recreation.gov. Last update 30 June 2003; retrieved 23 September 2003. Available URL: http://www.recreation.gov/detail.cfm?ID=3112. 
Carrizo Plain National Monument Fact Sheet and Mission Statement. 2003. Bureau of Land Management Bakersfield Field Office. Last update 2 May 2003; retrieved 8 September 2003. Available URL: http://www.ca.blm.gov/bakersfield/mission.html.

Columbia River Corridor. 2002. U.S. Fish and Wildlife: Hanford Reach National Monument. Last update August 2002; retrieved on 15 October 2003.

Available URL: http://hanfordreach.fws.gov/documents/riverfactsheet.pdf.

Description: Grand Staircase-Escalante National Monument. 2003. Desert USA. Retrieved 2 September 2003. Available URL: http://www.desertusa.com/escalante/du_esc_desc.html.

DOE/RL, see U.S. Department of Energy.

Facilities: Hanford Reach National Monument. 2002. U.S. Fish and Wildlife Service-Pacific Region. Last update August 2002; retrieved on 15 October 2003.

Available URL: http://hanfordreach.fws.gov/facilities.html.

Fishing: Black Canyon of the Gunnison National Park. 2003. National Park Service. Last update 16 September 2003; retrieved 8 September 2003.

Available URL: http://www.nps.gov/blca/webvc/fishing.htm.

Fitzner/Eberhardt Arid Lands Ecology Reserve. 2002. U.S. Fish and Wildlife Service: Hanford Reach National Monument. Last update August 2002; retrieved on 15 October 2003.

Available URL: http://hanfordreach.fws.gov/documents/alefactsheet.pdf.

Frequently Asked Questions. 2002. Cascade-Siskiyou National Monument. U.S. Bureau of Land Management-Oregon/Washington State Office-Medford District Office. Last update 2 August 2002; retrieved 9 September 2003. Available URL: http://www.or.blm.gov/CSNM/faq.htm.

General Public Use. U.S. Fish and Wildlife. Flyer Fall 2003. U.S. Fish and Wildlife: Hanford Reach National Monument. Last update August 2002; retrieved on 15 October 2003.

Available URL: http://hanfordreach.fws.gov/recreation.html.

Goodwin Education Center. 2003. Bureau of Land Management. Bakersfield Field Office. Last update 2 May 2003; retrieved 8 September 2003.

Available URL: http://www.ca.blm.gov/bakersfield/goodwin.html.

Grand Canyon-Parashant National Monument Fact Sheet. 2003. Bureau of Land Management Arizona State Office. Last update 21 August 2003; retrieved 8 September 2003.

Available URL: http://azwww.az.blm.gov/parashant/parashantfctsht.htm.

Grand Canyon-Parashant National Monument. 2003. Recreation.gov. Last update 30 June 2003; retrieved 23 September 2003. Available URL: http://www.recreation.gov/detail.cfm?ID=3108. 
Grand Staircase-Escalante National Monument Road Conditions. 2002. Bureau of Land Management. Grand Staircase-Escalante National Monument. Last update 11 July 2002; retrieved 2 September 2003. Available URL: http://www.ut.blm.gov/monument/Visitor_Information/road_conditions.html.

Grand Staircase-Escalante National Monument. 2003. Recreation.gov. Last update 30 June 2003; retrieved 23 September 2003. Available URL: http://www.recreation.gov/detail.cfm?ID=3120.

Hanford Engineer Works. 2003. The Children of the Manhattan Project. The Manhattan Project Heritage Preservation Association. Last updated 2 October 2003; retrieved 28 October 2003. Available URL: http://www.childrenofthemanhattanproject.org/HICC/HICC_HA.htm.

Hanford Reach National Monument Brochure. U.S. Fish and Wildlife. February 2003.

Hanford Site Selection. 2003. The Children of the Manhattan Project. The Manhattan Project Heritage Preservation Association. Last updated 2 October 2003; retrieved 28 October 2003.

Available URL: http://www.childrenofthemanhattanproject.org/HICC/HICC PD 4.htm.

Having Fun on the Monument. 2002. U.S. Fish and Wildlife: Hanford Reach National Monument. Last update August 2002; retrieved on 15 October 2003.

Available URL: http://hanfordreach.fws.gov/recreation.html.

Hiking the Monument. 2002. Bureau of Land Management. Grand Staircase-Escalante National Monument. Last update 11 July 2002; retrieved 2 September 2003.

Available URL: http://www.ut.blm.gov/monument/Visitor_Information/hiking.html.

Hiking: Black Canyon of the Gunnison National Park. 2003. National Park Service. Last update 16 September 2003; retrieved 8 September 2003.

Available URL: http://www.nps.gov/blca/webvc/hiking.htm.

Hiking/Biking. 2003. Carrizo Plain National Monument. Bureau of Land Management. Bakersfield Field Office. Last update 2 May 2003; retrieved 8 September 2003.

Available URL: http://www.ca.blm.gov/bakersfield/hikebikecpna.html.

Horseback Riding Routes. 2002. Grand Staircase-Escalante National Monument. Bureau of Land Management. Last update 11 July 2002; retrieved 2 September 2003.

Available URL: http://www.ut.blm.gov/monument/Visitor_Information/horse.html.

Horseback Riding: Carrizo Plain National Monument. 2003. Bureau of Land Management Bakersfield Field Office. Last update 2 May 2003; retrieved 8 September 2003.

Available URL: http://www.ca.blm.gov/bakersfield/horsebackridingcpna.html.

Horseback Riding: Black Canyon of the Gunnison National Park. 2003. National Park Service. Last update 16 September 2003; retrieved 8 September 2003.

Available URL: http://www.nps.gov/blca/webvc/horse.htm. 
Hunting. 2003. Carrizo Plain National Monument. Bureau of Land Management. Bakersfield Field Office. Last update 2 May 2003; retrieved 8 September 2003.

Available URL: http://www.ca.blm.gov/bakersfield/huntingcpna.html.

Hyatt Lake Recreation Complex. 2002. U.S. Bureau of Land Management. Oregon/Washington State Office. Medford District Office. Cascade Siskiyou National Monument. Last update 2 August 2002; retrieved 9 September 2003. Available URL: http://www.or.blm.gov/CSNM/Hyatt_Lake.htm.

McGee Ranch/Riverlands Unit. 2002. U.S. Fish and Wildlife: Hanford Reach National Monument. Last update August 2002; retrieved on 15 October 2003.

Available URL: http://hanfordreach.fws.gov/documents/mcgeefactsheet.pdf.

Mountain Biking Tours. 2002. Grand Staircase-Escalante National Monument. Bureau of Land

Management. Last update 11 July 2002; retrieved 2 September 2003.

Available URL: http://www.ut.blm.gov/monument/Visitor_Information/biking.html.

National Landscape Conservation System. 2002. U.S. Bureau of Land Management.

Oregon/Washington State Office. Medford District Office. Cascade-Siskiyou National Monument. Last update 2 August 2002; retrieved 9 September 2003.

Available URL: http://www.or.blm.gov/CSNM/nlcs.htm.

National Parks and Monuments. 2003. Encyclopedia.com. Last update 2003; retrieved September 2003. Available URL: http://www.encyclopedia.com/html/N/NatlP1kT1A1B1L1E1.asp.

Pacific Crest National Scenic Trail. 2002. U.S. Bureau of Land Management. Oregon/Washington State Office. Medford District Office. Cascade-Siskiyou National Monument. Last update 2 August 2002; retrieved 9 September 2003. Available URL: http://www.or.blm.gov/CSNM/Pacific_Crest_Trail.htm.

Parks. 2003. Aniakchak National Monument and Preserve. GORP.com. Retrieved 9 September 2003; retrieved URL: http://gorp.away.com/gorp/resource/us_nm/ak_aniak.htm.

Planning a Trip of the River. 2002. Bureau of Land Management. Lewiston Field Office. Last update 4 October 2002; retrieved 2 May 2004. Available URL: http://www.mt.blm.gov/ldo/fbtrip.html.

Proclamation. 2000. Establishment of the Hanford Reach National Monument. Presidential Documents. Proclamation 7319 of June 9, 2000. Retrieved 8 September, 2003. Available URL:

http://hanfordreach.fws.gov/documents/proclamation.pdf.

Regulations. 2002. U.S. Fish and Wildlife. Hanford Reach National Monument. Last update August 2002; retrieved on 15 October 2003. Available URL: http://hanfordreach.fws.gov/regulations.html.

Saddle Mountain Unit. 2002. U.S. Fish and Wildlife. Hanford Reach National Monument. Last update August 2002; retrieved on 15 October 2003.

Available URL: http://hanfordreach.fws.gov/documents/saddlemountainfactsheet.pdf. 
Site Dedication for Monument Interpretive Center. 2002. U.S. Fish and Wildlife. Hanford Reach National Monument. Last update: August 2002; retrieved on 22 December 2003.

Available URL: http://hanfordreach.fws.gov/documents/press/visitor-center-12-12-03.pdf.

The Monument's History. 2002. U.S. Fish and Wildlife. Hanford Reach National Monument. Last update August 2002; retrieved on 15 October 2003.

Available URL: http://hanfordreach.fws.gov/history.html.

Things You Need to Know. 2002. Bureau of Land Management. Grand Staircase-Escalante National Monument. Last update 11 July 2002; retrieved 2 September 2003.

Available URL: http://www.ut.blm.gov/monument/Visitor_Information/need_to_know.html.

U.S. Department of Energy, Richland Operations Office (DOE/RL). 2003. Hanford Long-Term

Stewardship Program and Transition: Preparing for Environmental Management Cleanup Completion. DOE/RL-2003-39. Richland, Washington.

U.S. Fish and Wildlife Service (USFWS). 2004a. 2004-2005 Fishing in Washington State Rule Pamphlet. Last update 2004; retrieved 23 June 2004. Available URL:

https://fortress.wa.gov/dfw/erules/efishrules/index.jsp

USFWS. 2004b. 2004-2005 Washington State Big Game Hunting Season and Rules Pamphlet. Last update 2004; retrieved 23 June 2004. Available URL: http://wdfw.wa.gov/wlm/game/hunter/hunter.htm

Upper Missouri River Breaks National Monument. 2003a. National Parks Service. U.S. Department of the Interior: Bureau of Land Management. Last update 11 April 2003; retrieved 8 September 2003.

Available URL: http://www.mt.blm.gov/ldo/um.

Upper Missouri River Breaks National Monument. 2003b. Recreation.gov. Last update 30 June 2003; retrieved 23 September 2003. Available URL: http://www.recreation.gov/detailcfm?ID=[3117].

Vernita Bridge Unit. 2002. U.S. Fish and Wildlife: Hanford Reach National Monument. Last update August 2002; retrieved on 15 October 2003.

Available URL: http://hanfordreach.fws.gov/documents/vernitafactsheet.pdf.

Visitor Information. 2003. Grand Canyon-Parashant National Monument. National Park Service. Last update 7 March 2003; retrieved 11 September 2003.

Available URL: http://www.nps.gov/para/access.html.

Visitor Information. 2002. U.S. Bureau of Land Management. Oregon/Washington State Office.

Medford District Office. Cascade-Siskiyou National Monument. Last update 2 August 2002; retrieved 9 September 2003. Available URL: http://www.or.blm.gov/CSNM/visitor_info.htm.

Wahluke Unit. 2002. U.S. Fish and Wildlife: Hanford Reach National Monument. Last update August 2002; retrieved on 15 October 2003.

Available URL: http://hanfordreach.fws.gov/documents/wahlukefactsheet.pdf. 
Wildlife and Environmental Studies. 2003. Picture This by Media Type. Pacific Northwest National Laboratory. Last update: December 2003. Retrieved December 2003. Available URL:

http://picturethis.pnl.gov/picturet.nsf/frameset/media?opendocument. (Click on Graphics and then Wildlife and Environmental Studies.)

Wildlife Watching. 2003. National Park Service Black Canyon of the Gunnison National Monument. Last update 16 September 2003; retrieved 8 September 2003. Available URL:

http://www.nps.gov/blca/webvc/wildwtch.htm 


\section{Distribution}

No. of

Copies

ONSITE

18 Pacific Northwest National Laboratory

M.E. Hevland

K7-97

G. M. Gelston

K7-97

A. L. Bunn

K6-85

J. Pospical (8)

K8-03

Information Release Office (7)

K1-06

Distr.1 